Beitrag / Article

Open Access

Britta Stöver*

\title{
The regional significance of university locations in Lower Saxony
}

\section{Die regionale Bedeutung von Hochschulen in Niedersachsen}

https://doi.org/10.2478/rara-2020-0014

Eingegangen: 27. Juni 2019; Angenommen: 25. März 2020

\begin{abstract}
Universities are important economic actors and make a considerable impact on the demand and supply side of their local economies. The aim of this paper is to quantify, compare and classify the different economic demandand supply-side contributions of the university locations within Lower Saxony (Germany) using a combination of multiplier analysis and spatial econometrics on a NUTS 3 level. In comparison to numerous other studies, this paper does not focus on the economic impact of individual cases or a selected university location but gives a complete picture of the importance and significance of all university locations within Lower Saxony. The income-induced direct and indirect demand effects are estimated using a rich data set of higher education statistics in combination with an income and employment multiplier derived from a regional input-output table. The supply-side effects, i.e. the impact of the education and research outcomes, are estimated with the help of spatial panel regressions, a model derived from human capital theory and knowledge spillover theory. The estimation results give a complete and reproducible impression of the importance and significance of the different university locations, offering the opportunity for comparisons and classifications.
\end{abstract}

Keywords: Demand- and supply-side effects, multiplier analysis, spatial panel model, university locations, Lower Saxony

Kurzfassung: Hochschulen sind wichtige Wirtschaftsakteure und haben einen erheblichen Einfluss auf Angebot und Nachfrage in ihrer regionalen Wirtschaft. Ziel dieser Arbeit ist es, die unterschiedlichen wirtschaftlichen nachfrage- und angebotsseitigen Beiträge der niedersächsischen Hochschulstandorte mithilfe einer Kombination aus Multiplikatoranalyse und räumlicher Ökonometrie (spatial panel) auf NUTS 3-Ebene zu quantifizieren, zu vergleichen und zu klassifizieren. Im Vergleich zu zahlreichen anderen Studien, welche die ökonomische Bewertung von Hochschulstandorten vornehmen, stellt dieser Beitrag nicht auf die wirtschaftlichen Auswirkungen einer bestimmten Hochschule bzw. Hochschulregion ab, sondern bietet ein umfassendes, vollständiges und konsistentes Bild aller Hochschulstandorte in Niedersachsen. Die einkommensinduzierten direkten und indirekten Nachfrageeffekte werden anhand eines detaillierten Datensatzes der Hochschulstatistik in Kombination mit Einkommens- und Beschäftigungsmultiplikatoren aus einer regionalen Input-Output-Tabelle berechnet. Die angebotsseitigen Effekte, das heißt die Auswirkungen von Bildung und Forschungsergebnissen, werden mithilfe von Spatial-panel-Regressionen geschätzt, einem Modell, das aus der Humankapitaltheorie und der Theorie zur

*Corresponding author: Britta Stöver, Leibniz Universität Hannover, Institut für Statistik, Königsworther Platz 1, 30167 Hannover, Deutschland, E-Mail: stoever@statistik.uni-hannover.de 
Wissensverbreitung (knowledge spillover theory) abgeleitet ist. Die Schätzergebnisse vermitteln einen vollständigen und nachvollziehbaren Eindruck von der wirtschaftlichen Bedeutung der verschiedenen Hochschulstandorte in Niedersachsen und ermöglichen Vergleiche zwischen den Standorten sowie Einordnungen bzw. Gruppierungen.

Schlüsselwörter: Angebots- und nachfrageseitige Effekte, Multiplikatoranalyse, räumlich-ökonometrisches Modell, Hochschulstandorte, Niedersachsen

\section{Introduction}

Universities are important economic actors that affect the local economy in two ways. On the demand side they consume labour and materials for the provision of education and administrative tasks, inducing direct and indirect multiplier effects. On the supply side they generate human capital by educating students. Additionally, many research findings suggest that universities regionally support innovation and development as well as the foundation of new ventures. Another important output arises out of their role as household-related infrastructure influencing and enhancing socio-cultural activities (Benson 2000: 14-16; Stoetzer/Krähmer 2007: 4-5; Warnecke 2016: 23-34): a university (often) goes hand-in-hand with academic libraries, cultural events, public lecture series, (botanical) gardens, a rejuvenation of the cityscape due to the students, greater gastronomic diversity and so on. These university-related outputs increase the local quality of life.

The quantification of the significance and the economic value of universities for their respective regions is of interest to local politicians as well as to the universities themselves. The findings help to legitimate public funding and the use of tax money. They can support image campaigns and reform or investment programmes. As a consequence, there are already numerous national and international publications evaluating the economic importance of universities. ${ }^{1}$

The multiplier analysis was established as the best method to determine the indirect and induced demandside effects. The multiplier itself can be estimated in two ways: either using a regional input-output model (Type-I multiplier) or with a simple Keynesian demand-driven growth model (Keynesian multiplier). For Germany, the

1 An overview of German studies published in the 1990s is given in Blume and Fromm (1999: 419) and Blume and Fromm (2000: 120), results of German studies published in the 2000s are summarised e.g. in Pavel (2008: 20). Additionally, Stoetzer and Krähmer (2007) provide an extensive discussion on the results of German demandrelated studies published between 1966 and 2006. An overview of American studies is given in Blackwell, Cobb and Weinberg (2002). majority of the studies conducted since the year 2000 use the Keynesian multiplier for the calculation of the indirect and induced demand-side effects (Assenmacher/ Leßmann/Wehrt 2004; Knappe 2006; Färber/Dalezios/ Arndt et al. 2007; Leusing 2007; Pavel 2008; Mattes 2012; Hamm/Kopper 2016). This is because the German Federal Statistical Office provides input-output tables exclusively at the national level and the calculation of the Keynesian multiplier avoids the time-consuming creation of a regional input-output table. The estimated Keynesian income multipliers differ considerably and take values between 1.01 (Knappe 2006) and 2.6 (Hamm/Kopper 2016). The huge discrepancies are due to the fact that the multiplier is sensitive to the size of the investigated region, the present economic structure and import quotas, the definition of the university-related income, consumption expenditures and employment relationships, as well as the local propensity to consume (Back/Fürst 2011: 4).

Input-output related income and employment multipliers (or a combination of both kinds of multipliers) are only applied by Blume and Fromm (2000), Hamm and Wenke (2002), Spehl, Sauerborn, Sauer et al. (2005) and Glückler, Panitz and Wuttke (2015). The estimated values range between 1.0 (Spehl/Sauerborn/Sauer et al. 2005) and 1.5 (Blume/Fromm 2000). Again, the amount of the multiplier depends on the size of the region: the smaller the area under consideration the more likely it is that the multiplier values are low as most probably many goods have to be imported from outside the region (Farhauer/Kröll 2013: 416).

The supply-side effects, i.e. the positive impact on local economic growth of providing qualifications and innovation, are neglected by a lot of the studies. Favoured procedures used by studies considering the supply-side effects are the qualitative analysis and quantitative evaluation of interviews and questionnaires (Blume/Fromm 2000; Hamm/Wenke 2002; Assenmacher/Leßmann/Wehrt 2004; Gerlach/ Sauer/Stoetzer 2005; Knappe 2006; Pavel 2008; Mattes 2012; Hamm/Kopper 2016). These papers deduce the positive regional impact of the supply-side effects from 
the endogenous growth theory of Romer (1986) and Lucas (1988): educating students and doing research can be interpreted as an investment in human capital resulting in the accumulation of knowledge, an increase in productivity and the generation of innovation. In combination with the assumed existence of knowledge spillovers this leads to higher economic growth within the region. However, almost all of the aforementioned papers take the positive relationship between university output (graduates, research, co-operations) and local economic growth/innovation as given and rather focus on the proportions of graduates entering the local labour market and the number of knowledge networks and co-operations between university and local companies. Consequently, the local portion of the university-specific output is implicitly assumed to have a positive effect on the local economy and its innovation. Pavel (2008) and Mattes (2012) supplement the descriptive analysis and stocktaking of networks, spin-offs and patents by estimating the growth effects using a production function and findings from literature: the economic impact of the knowledge capital results from its marginal productivity estimated to be $0.5 .^{2}$ This means that an increase in knowledge capital of one euro results in an increase in value added of 0.5 euros. Factors that lead to the increase in knowledge capital are not discussed.

The only study (to the knowledge of the author) that uses a completely different approach and estimates the demand- as well as the supply-side effects of all universities within Germany with regression functions, is that of Schubert and Kroll (2013).

All studies indicated above have in common that they are either single case studies focusing on individual universities and the impact on their respective university locations (Blume/Fromm 2000; Hamm/Wenke 2002; Assenmacher/Leßmann/Wehrt 2004, Knappe 2006; Leusing 2007; Pavel 2008; Mattes 2012; Hamm/Kopper 2016) or global studies considering the sum of universities in a federal state and the impact on the entire federal state in question (Glückler/Panitz/Wuttke 2015).

The only exception with regard to the regional dimensions is Spehl, Sauerborn, Sauer et al. (2005). They analyse the total demand effects for the federal state of Rhineland-Palatinate as well as for each university location within Rhineland-Palatinate separately.

2 Both authors conducted their studies on behalf of the consulting company DIWecon, which might explain the similar approach. According to Mattes (2012: 35), the value of 0.5 was estimated by a number of relevant research studies. Pavel (2008: 37-38) refers to findings for Australia, the US and other OECD countries.
However, a comparison of the individual contributions of each university location and a spatial classification is not included. With regard to all German studies, the findings are often based on different definitions of the spatial dimensions as well as on different statistical and empirical methods (Blume/Fromm 1999: 418). Thus, a classification, combination and comparison of the different local results is not straightforward.

This paper aims to determine the importance of each university location within Lower Saxony in relation to its own local economy as well as in comparison with the other university locations, and tries to detect spatial disparities or patterns. The objective is to quantify, compare and classify the different economic demandand supply-side contributions of each university location within Lower Saxony using the well-established multiplier analysis for the demand-side effects and an alternative approach based on spatial econometrics for the supplyside effects on NUTS 3 level. $^{3}$

The demand-side driven economic impact of the university locations on the local economy and the local labour market is estimated using multiplier analysis. The income-induced direct and indirect demand effects are estimated with a rich data set of higher education statistics in combination with an income and employment multiplier derived from a regional input-output table. Contrary to the demand side, there are no monetary values for the supply-side effects, i.e. for the education and research outcomes. While the demand side is hence relatively easily quantifiable, the economic value of providing highly educated manpower and research cannot be measured directly. As a consequence, the supply-side effects are determined by estimates from spatial panel regressions, a model derived from human capital theory and knowledge spillover theory. Contrary to the existing German studies (Blume/Fromm 2000; Hamm/Wenke 2002; Assenmacher/Leßmann/Wehrt 2004; Gerlach/ Sauer/Stoetzer 2005; Knappe 2006; Pavel 2008; Mattes 2012; Hamm/Kopper 2016), this contribution takes the existence of university-company networks and the local presence of graduates as given and tries to quantify the effect of the individual university locations on their local economic growth and innovation. Based on the consistent data set and the well-defined methodology,

3 The NUTS classification (Nomenclature of territorial units for statistics) is a hierarchical system for dividing up the economic territory of the EU (https://ec.europa.eu/eurostat/web/nuts/ background; 30.01.2020). For Germany, NUTS 1 represents the geographic division into the 16 Länder (federal states), NUTS 3 the division into $401 \mathrm{Kreise} / \mathrm{kreisfreie}$ Städte (https://ec.europa.eu/ eurostat/web/nuts/national-structures-eu; 30.01.2020). 
NUTS-3 region with university location

- university location

size of the university location (in number of enrolled students)
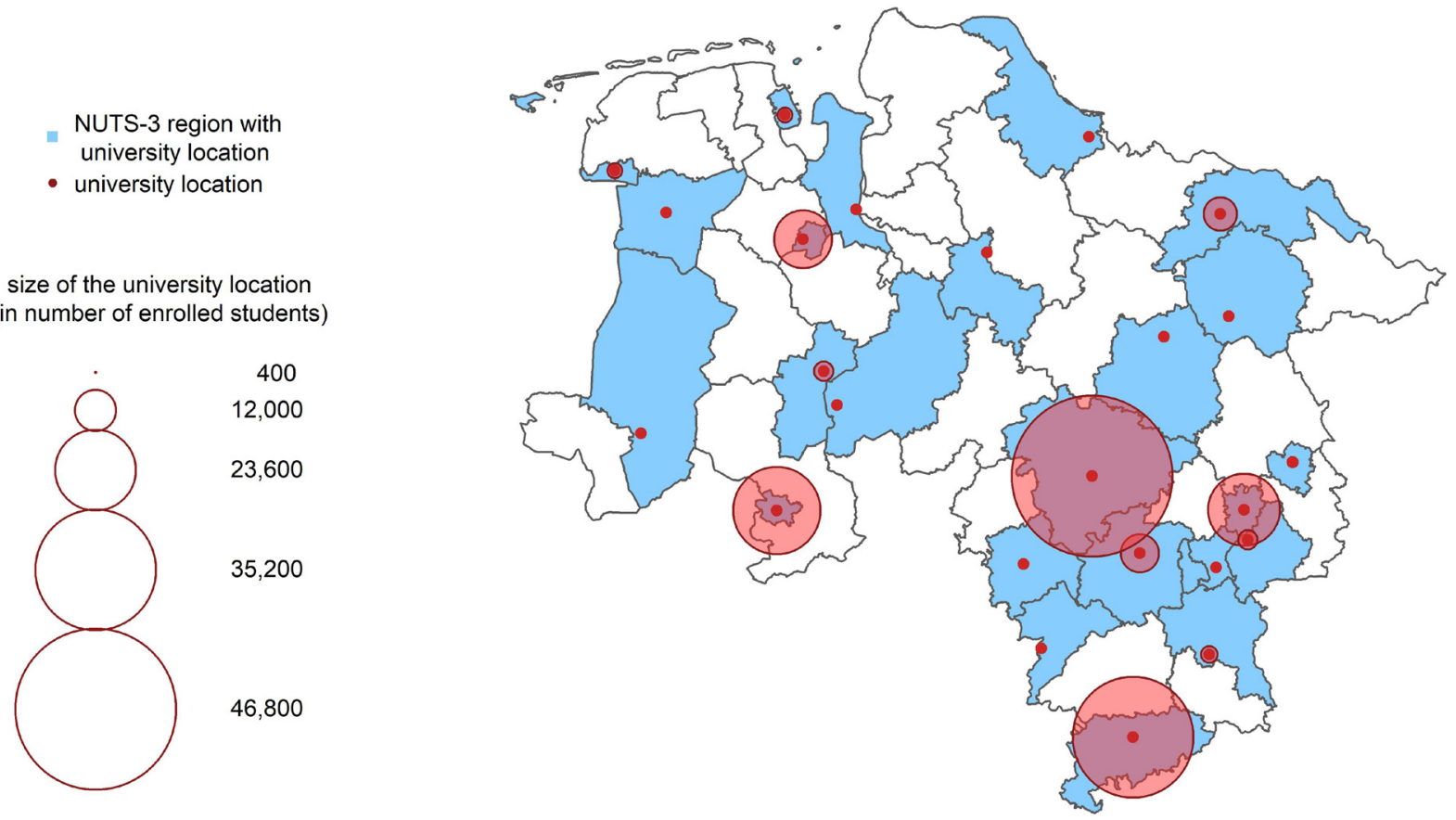

Figure 1: Size and distribution of university locations in Lower Saxony (2016) Source: Statistisches Landesamt Niedersachsen (higher education statistics, different volumes), author's own calculations. Map: GADM data, Version 2.8.

the estimation results provide an opportunity to assess the importance and significance of each university location in Lower Saxony for their respective region, in relation to the other university locations and in total for Lower Saxony.

The paper is structured as follows. In Section 2 some background information about the dataset, terminologies and the university landscape in Lower Saxony is given. Section 3 deals with the demand-side contribution of the university locations, first introducing the methodology and then presenting the related results. Section 4 follows the same structure as Section 3 but refers to the supplyside contributions. In Section 5 the paper is summarised and discussed.

\section{Background, definitions and data sources}

In 2016, 205,000 students were enrolled in 30 universities at 24 locations in Lower Saxony. ${ }^{4}$ The majority of regions

4 The general information in this paragraph includes the university location Hermannsburg though this location is later excluded in the estimation process. within Lower Saxony - 24 out of 45 NUTS 3 regions have at least one university. The university locations can be found in urban as well as rural areas and vary considerably in size (see Figure 1). Overall, 51,800 persons are employed in universities with the majority $(52.8 \%)$ being scientific personnel.

The significance and economic importance of university locations for their region consists of the effects arising from the universities' inputs (demand) and outputs (supply). The structure of the demand-side as well as supply-side effects are summarised in Figure 2.

The university-related demand is composed of expenditures for materials, personnel and investment as well as the private consumption of students. The direct demand effects are the sum of the expenses incurred within the region, i.e. the products and services bought from local producers as well as the local consumption of the university personnel and the students. Indirect effects occur due to the sectoral interrelations and interdependencies of the economic actors: in order to meet the university-related direct demand, the producers use intermediate inputs from other (or their own) economic activities that positively affect production and trigger additional incomes (via salaries and wages) in the respective region. The indirect effects can be estimated using the Type-I income multipliers derived 

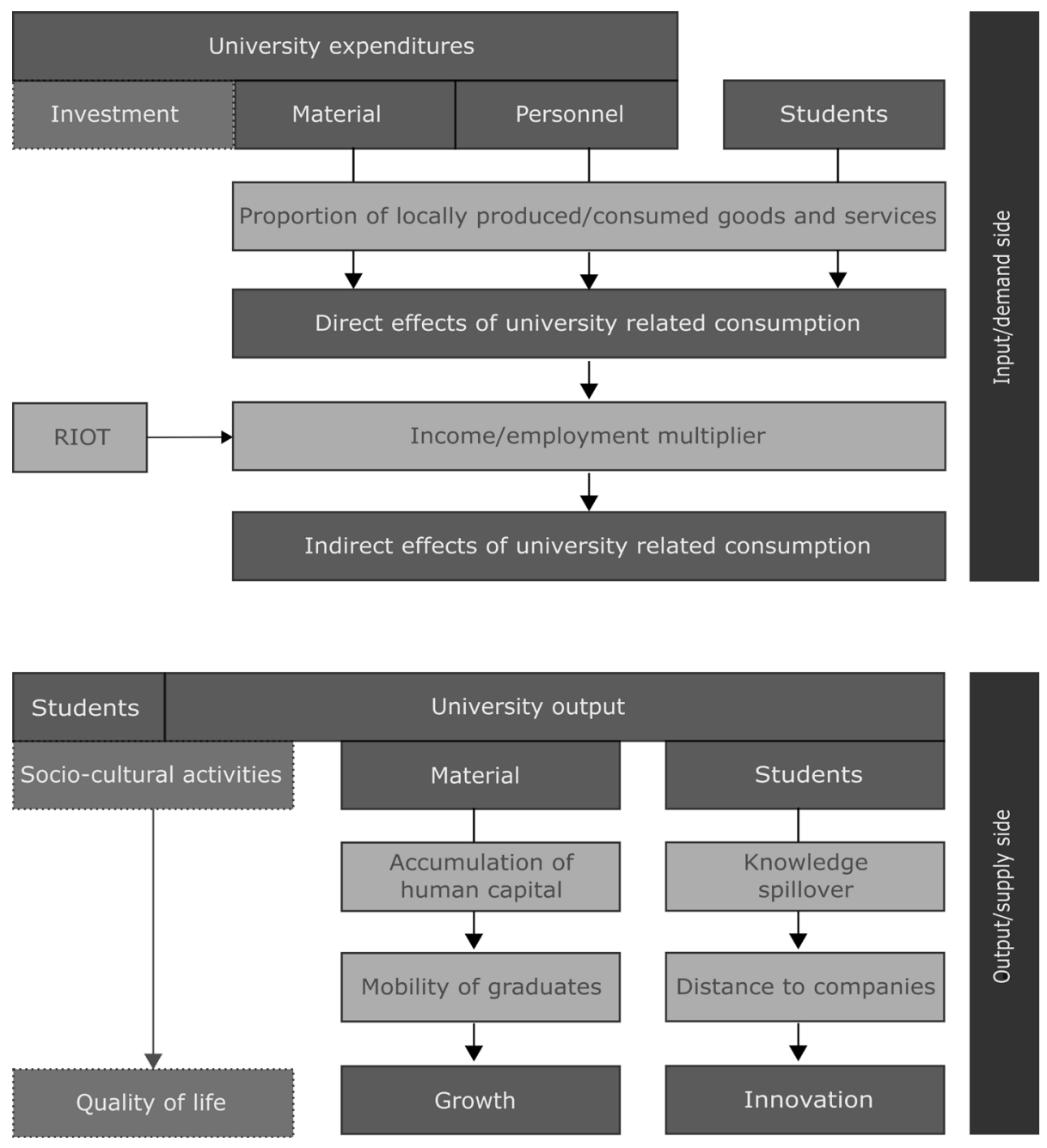

Figure 2: Demand- and supply-side contributions of universities

from an input-output table (IOT) (Holub/Schnabel 1994: 461-483; Farhauer/Kröll 2013: 417-420). With regard to employment, direct employment effects are represented by the university personnel, indirect effects arise out of the labour needed for the intermediate inputs described above and can be determined by the input-output table based on Type-I employment multipliers (Farhauer/ Kröll 2013: 420-422). The additional incomes thus generated (indirect income effect) are again used for consumption, triggering further income and employment effects - called induced effects. These effects can be derived with Type-II income and employment multipliers in combination with an extended input-output table (Holub/Schnabel 1994: 467). However, due to data restrictions, estimation of the Type-II income multipliers is not feasible for Germany (Farhauer/Kröll 2013: 420). In general, the value of the induced effects is rather small: Glückler, Panitz and Wuttke (2015: 335) find that they only contribute $1.6 \%$ to the total income effects. ${ }^{5}$ The underestimation of the total effects could be considered of lower significance (especially when keeping in mind all the necessary assumptions during the estimation process that contribute to the general level of uncertainty of the results). ${ }^{6}$ Additionally, according to Pfähler, Bönte, Gabriel et al. (1999: 61) and Spehl, Sauerborn, Sauer et al. (2005: 64) the induced income effects do not generate additional income in the region, but merely show the

5 Due to different definitions regarding direct, indirect and induced effects, the proportions of the induced effects in other studies may be much higher. In these cases, the induced effects often include indirect effects according to the definition given above.

6 The application of a Keynesian multiplier would result in the estimation of indirect and induced income effects (as a sum). The reasons why the multipliers based on the input-output table were preferred over the Keynesian ones are given in Section 3.1. 
dispersal and circulation of the income, resulting in double (or multiple) counting.

The output or supply of universities consists of education and research and in a broader sense includes socio-cultural contributions such as concerts, cultural events, public lectures or the maintenance of libraries, botanical gardens and historical buildings. The education of students positively affects the accumulation of human capital, fostering economic growth. The research output of universities has a positive impact on innovation due to knowledge spillovers. Socio-cultural activities positively influence the local quality of life. The latter is not measurable/quantifiable (Stoetzer/Krähmer 2007: 4-5) and is hence not part of this analysis. The mechanisms through which the education and research output of universities becomes effective in its regions are described in more detail in Section 4.1.

While the demand-side effects (expenses and their multiplier effects) can be estimated in terms of monetary value, the supply-side effects can only be indirectly quantified. Before going into methodological detail some general information about data sources and terminologies is given.

Almost all values used in this analysis are derived from official statistics: university-related information is provided by higher education statistics (Landesamt für Statistik Niedersachsen). ${ }^{7}$ Information on GDP and the labour market are derived from the Statistische Ämter des Bundes und der Länder. ${ }^{8}$ Values regarding migration, commuting and population are published by Regionaldatenbank Deutschland..$^{9}$ The Household Budget Survey is provided by the Statistical Office in Lower Saxony (Landesamt für Statistik Niedersachsen) ${ }^{10}$

7 Hochschulstatistik, verschiedene Jahrgänge, Auswertung aus der ICE-Datenbank der Länderministerien (ICE = Information, Controlling, Entscheidung).

8 Volkswirtschaftliche Gesamtrechnungen der Länder: Bruttoinlandsprodukt, Bruttowertschöpfung in den kreisfreien Städten und Landkreisen der Bundesrepublik Deutschland 1992 und 1994 bis 2016.

9 Sozialversicherungspflichtig Beschäftigte am Arbeits- und Wohnort sowie Ein- und Auspendler über Kreisgrenzen nach Geschlecht, Stichtag 30. Juni, Kreise und kreisfreie Städte. Auszug aus der Regionaldatenbank, Version 2.0. Stand: 27. Oktober 2017 / 15:06:20; Bevölkerung nach Geschlecht und Altersjahren, Stichtag 31. Dezember, regionale Tiefe: Kreise und kreisfreie Städte. Auszug aus der Regionaldatenbank, Version 2.0. Verschiedene Jahrgänge; Zu- und Fortzüge (über Kreisgrenzen) nach Geschlecht und Nationalität, Jahressumme, regionale Tiefe: Kreise und kreisfreie Städte. Auszug aus der Regionaldatenbank, Version 2.0. Stand: 8. Januar 2019 / 07:13:51.

10 Konsumausgaben privater Haushalte 2013 nach der sozialen Stellung der Haupteinkommensbezieher/-innen. Auswertungsta- and information on patents is given by the European Patent Office (EPO). Only the information on the cost and import structure of the material expenditures of the universities is derived from a specifically conducted sample. ${ }^{11}$

The term university encompasses all kinds of universities in Lower Saxony listed in the higher education statistics. ${ }^{12}$ This includes private universities as well as Universities of Applied Sciences. University hospitals are part of the university definition as well. Institutions related to universities but not directly part of them such as the Studentenwerk (dormitories, canteen for students, kindergarten or day-care centres) or nonuniversity research facilities (i.e. Helmholtz Association, Max Planck Society, Fraunhofer-Gesellschaft) are not included. Also excluded are university visitors and their demand (participants in conferences or workshops, visiting professors) due to missing data.

Regions are defined by the NUTS 3 administrative borders (kreisfreie Städte und Kreise) and university location is hence a region in which one or more universities are located.

The analysis of the demand-side effects addresses the question of how much each university location contributes in monetary terms and number of jobs to its region. The reference is a situation where no university is present in the university location. The analysis focuses on a static and short-term horizon as no compensating reactions due to the non-existence of a university or alternative uses of the university budget are considered. The analysis of the supply-side effects addresses the question of how much each university location affects the economic and innovative development in its region. The reference situation is given by changes in the university environment (represented by the explanatory variables), e.g. by an increase in the number of graduates. Therefore, the timeframes investigated differ as well: the short-term horizon demand-side effects refer to the year 2016. The

belle des Statistischen Landesamtes Niedersachsen aus der EVS 2013.

11 The universities Ostfalia, Hochschule Hannover, Hochschule für angewandte Wissenschaft und Kunst (HAWK) and TU Braunschweig were willing to provide the special information about their cost structures and the author was very grateful for their cooperation.

12 The university in Hermannsburg is excluded as a university location because it is a new university that was founded in 2012 . As it is also a very small university with only 83 enrolled students in 2017 and with little economic impact, it has been excluded from the data set to avoid a shortening of the time series of the panel. 
medium to long-term supply-side effects encompass the time period 2010-2016.

\section{The demand-side contributions of the university locations}

The demand-side contribution of each university location is quantified using multiplier analysis based on an inputoutput table (Type I multipliers, see discussion in Section 2). With the choice of the input-output-table-based multiplier the induced effects have to be neglected. Nevertheless, the input-output-table-based multiplier is preferred over the alternative approach of the Keynesian multiplier for several reasons. Thus the Keynesian multiplier is based on a relatively simple model with a multitude of assumptions as well as aggregated data resulting in a loss of accuracy and neglect of the sectoral specific contribution to the income effects (Pfähler/Clermont/Gabriel et al. 1997: 68; Stoetzer/ Krähmer 2007: 37). As the multiplier is based solely on aggregated values related to general characteristics of the region it remains the same for different research objects (Pfähler/Clermont/Gabriel et al. 1997: 68). As a consequence, the values of the Keynesian multipliers are in general higher than those deduced from an inputoutput table (Spehl/Sauerborn/Sauer et al. 2005: 94). The level of the induced effects as determined using a Keynesian multiplier most decisively depends on the values for marginal propensity to consume and the local import quota. Spehl, Sauerborn, Sauer et al. (2005: 51) show that the (realistic) choice of a marginal propensity to consume of between 0.8 and 0.9 and of an import quota of between 0.6 and 0.85 already result in multiplier values ranging between 1.14 and 1.56 . The values for local import quotas are in general unknown, depend on the local production structures, and their estimation requires a great deal of effort (Assenmacher/Leßmann/ Wehrt 2004: 27).

In contrast, the input-output approach considers the specific composition of the economy and the structure of intermediated consumption. Quotas do not need to be set as they are part of the consistent input-output underlying the Leontief model. Consequently, the best approach for estimation of the indirect effects is to employ an input-output table as this solution has the best theoretical foundation (Blume/Fromm 2000: 32; Hamm/ Kopper 2016: 66).
It has to be noted that the focus of the demand-side analysis in this paper is on the university location itself, i.e. the contribution of the university or universities to its/their own region/s and in comparison to the others. Spillover effects into other, especially neighbouring, regions are not considered. The reasons for the exclusion of the spillover effects are, on the one hand, data restrictions and, on the other hand, the interpretability of the results. On the data side, commuting activities are only published as total inflows and outflows without destination information. Assumptions regarding the nonlocal part of the consumption expenditure of university personnel and students would then need to be set, which would add to the uncertainty and errors of the results. Additionally, two neighbouring university locations affect each other through the non-local consumption of their commuting university personnel/students, blurring the original contribution of each individual university location to its region. Nevertheless, the spillovers are indirectly accounted for in the estimation of the total demandside contribution for Lower Saxony as a whole: the total contribution is not the mere sum of each university location's contribution, but was estimated separately.

\subsection{Measuring the demand-side contribution}

In the study at hand the direct and indirect demand-side effects are estimated using a rich data set with financial and economic information on NUTS 3 level as well as income and employment multipliers derived from a regional input-output table. The variables and calculation procedures are as proposed by Caffrey and Isaacs (1971) and Garrido-Yserte and Gallo-Rivera (2010). ${ }^{13}$

A difference to the general approach is, however, that the estimation concentrates on the direct and indirect demand effects originating from the recurrent consumption expenditure of the university personnel and the students as well as the university's material expenditures. Investment expenditures are excluded because they only take place on an irregular basis. The amount and timing of investments varies a lot between the university locations, making the selection of a reference year difficult. In order to avoid an overestimation of the regional impact of university

13 There have been many applications of this methodology, see e.g. Bauer (1997), Blume/Fromm (2000) or Glückler/König (2011) for German case studies or Pellenbarg (2007), University of Colorado (2017) or Tripp Umbach (2018) for international ones. 
locations, the positive demand effects arising out of expenses for investment are not taken into account. This procedure can also be justified by the fact that the staff and material expenditures account for the biggest share of total expenses for personnel, materials and investment, over $90 \%$. Nevertheless, it should be kept in mind that the results tend to underestimate the local economic contribution of the university locations.

The demand effects arising out of the expenses for material are not easily estimated: in official data provided by the Regional Statistical Office or the Federal Statistical Office little is known about the regional share of material expenditure, i.e. the proportion of materials bought from local producers. Therefore, samples have been investigated at a few selected universities. The results suggest that most of the products for material expenses are imported from other (mostly neighbouring) NUTS 3 regions: $42 \%$ of the universities' expenditure on material goes to local producers, $58 \%$ to producers outside the respective region. The high proportions of imported intermediate inputs on NUTS 3 level is comparable with findings from Hamm and Kopper (2016:70) for the Niederrhein University in North RhineWestphalia or from Oser and Schroeder (1995: 2) for the University of Konstanz in Baden-Württemberg. However, Stoetzer and Krähmer (2007: 27) state that the proportion of regionally produced intermediate inputs for material expenses depends on the characteristics of the studied region (i.e. size, economic structure, geographic location) and can vary considerably. Nevertheless, due to the data restrictions it is assumed that the survey results from the selected universities represent the composition and local shares of material expenses for each university location in Lower Saxony. On NUTS 1 level, the results of the regional input-output table for Lower Saxony suggest that only $7.4 \%$ of the intermediate inputs consumed by universities are imported from other federal states or countries. In detail, the locally operative part of the material expenditures is then calculated by

$$
L C_{M}=M E X P * L S, \text { with } L S=0.42 \forall \text { regions }
$$

With $L C_{M}$ representing the local consumption of material, MEXP being the university-related material expenses at the university location and $L S$ being the share of the material expenses provided by local producers.

For the calculation of the direct and indirect demand effects related to the private consumption of the university personnel and the students, it is assumed that the disposable income of university personnel and students is not spent completely. Additionally, only part of the consumption is spent locally due to commuting as well as to holiday and business trips undertaken by employees and students.

The local consumption of the university personnel is estimated as follows:

$$
\begin{aligned}
& D I N C_{U P}=S E X P_{U P}-P T_{U P}-T \& S S C_{U P} \\
& C_{U P}=D I N C_{U P} * A P C_{U P} \\
& L C_{U P}=C_{U P} * 0.9 *(1-I C R)+C_{U P} * 0.1 * I C R
\end{aligned}
$$

with DINC being the disposable income of the university personnel. It is estimated by subtracting the payroll taxes $(P T)$ as well as the taxes and social security contributions (T\&SSC) from the staff expenditure (SEXP). The calculation procedure differentiates between different employment relationships. ${ }^{14} C_{U P}$ represents the total consumption expenditure of the university personnel depending on the average propensity to consume $(A P C))^{15}$ The average propensity to consume for different household types can be derived from the Household Budget Survey. However, the information is only available at NUTS 1 level for Lower Saxony. It is therefore assumed that there are no spatial differences and that the propensity to consume is equal in all NUTS 3 regions. $L C_{U P}$ is the local consumption expenditure, i.e. the amount of consumption expenditure spent at the university location and not elsewhere. It depends on the share of commuters working at the university location. It is assumed that the share of in-commuters among total university personnel is as high as in the total local labour market. The local consumption is then estimated assuming that university personnel living at the university location spend $90 \%$ of their consumption locally whereas university personnel in-commuting from another NUTS 3 region spend only $10 \%$ of their consumption at the university location. ${ }^{16}$

The amount that is locally consumed by students is estimated by

$$
C_{S}=D I N C_{S} * A P C_{S}, \text { with } A P C_{S}=0.9536 \forall S
$$

14 The university personnel consist of employees and Beamte. The difference between the two types of civil servants is expressed (among other things) in the type and amount of social security contributions and hence in the level of disposable income.

15 Again, a distinction is made between the different consumption behaviour of employees and Beamte.

16 The shares in local consumption are taken from Blume and Fromm (1999: 422). 


$$
L C_{S}=0.8 * C_{S}
$$

The disposable income $D I N C_{S}$ and the average propensity to consume $A P C_{s}$ is information derived from the Household Budget Survey. Again, the information is only available at NUTS 1 level for Lower Saxony and it is hence assumed that the disposable income and the propensity to consume for each student in every NUTS 3 region is the same. ${ }^{17}$ As for the local part of the total students' consumption $\left(L C_{S}\right)$ an $80 \%$ share is used. This assumption was derived from Blume and Fromm (1999: 423).

The combination of the local consumption of the university personnel and students with the university's expenses for material yields the total direct demand effects. The total (indirect and direct) effects can be derived by using the income multiplier from the regional input-output table for Lower Saxony (Stöver 2018), called Type-I-Income Multiplier (Farhauer/Kröll 2013: 417). The income multiplier is estimated by

$$
\begin{aligned}
& I M=\frac{\text { income.ef }}{a_{m l}} \\
& \text { income.ef }=a_{m l}^{\prime} *(I-A)^{-1} \\
& a_{m l}=\frac{\text { comp.empl }}{\text { production }}
\end{aligned}
$$

The income multiplier $I M$ is composed of the total direct and indirect income effect income.ef and the monetary labour input coefficient $a_{m l}$. The monetary labour input coefficient $a_{m l}$ - also representing the direct income effect - is given by the compensation of employees (comp.empl) per production unit. ${ }^{18}$ The total (in)direct income effect income.ef is the product of the labour input coefficient vector with the Leontief inverse $(I-A)^{-1}$.

The estimated direct and indirect income-induced demand effect leads to higher local production than would have occurred if the university location did not exist. For

17 The Household Budget Survey information was preferred to the information provided by HIS (Sozialerhebung des Deutschen Studentenwerks) as it offered more precise monetary values on the same spatial level. Additionally, the information from the Household Budget Survey was also used for the construction of the regional input-output table and the estimation of the consumption expenditure of the university personnel. Thus, the further usage of the Household Budget Survey for the students' consumption expenditure allowed for an overall consistent data base.

18 Production is estimated using the definition of the Statistical Office for non-market producers, i.e. producers such as the government, non-profit organisations or public universities whose services are not sold but are mainly provided as public goods. Accordingly, production is the sum of expenditures (e.g. compensation of employees, intermediate input, depreciation). this extra production additional labour is necessary, i.e. the indirect employment effect that supplements the labour demand for university personnel. The total direct and indirect employment effect Empl.Effect is then the sum of the number of university employees uni.personnel and the additional labour demand indir.empl estimated by:

$$
\begin{aligned}
& \text { Empl.Effect }=\text { uni.personnel }+ \text { indir. empl } \\
& \text { indir.empl }=\text { income.ef } *\left(\text { empl.ef }-a_{\iota}\right) \\
& \text { empl.ef }=a_{\iota}^{\prime} *(I-A)^{-1} \\
& a_{\iota}=\frac{\text { uni.personnel }}{\text { production }}
\end{aligned}
$$

The indirect employment effect indir.ef is the difference between the total employment effect empl.ef (estimated from the Leontief inverse) and the physical labour input coefficient $a_{i}$. The physical labour input coefficient - also representing the direct employment effect - is given by the number of university employees per production unit.

\subsection{Results of the demand-side contributions}

The total direct demand effects related to the universities' material expenses as well as the private consumption expenditures of university personnel and students range from a maximum of 820.6 million euros in Hannover (Region Hannover) to a minimum of 2.4 million euros in Diepholz (Landkreis Diepholz) (see Table 1). ${ }^{19}$ The direct demand effects are not equally distributed between the university locations: only five out of the 24 university locations lie above the average value of 106.8 million euros. These university locations are Hannover (Region Hannover), Göttingen (Landkreis Göttingen), Braunschweig (kreisfreie Stadt Braunschweig), Osnabrück (kreisfreie Stadt Osnabrück) and Oldenburg (kreisfreie Stadt Oldenburg). The median university location accounts for 36.1 million euros direct local demand. This implies that the highest direct demand effects can be associated with just a few university locations mainly located in the south of Lower Saxony, while the majority of the university locations contribute less than 36.1 million euros in terms of demand to their local economy (see also the left-hand map in Figure 3). The university locations in the lower quartile show direct

19 The university location is given before the brackets, in the brackets is the name of the related NUTS 3 region. 
Table 1: Direct demand effects and indirect demand-related income effects (in 1,000 euros)

\begin{tabular}{|c|c|c|c|c|c|c|c|c|}
\hline University location & LC.M & LC.UP & LC.S & TLC & IM & I.IE & TDE & S.GDP \\
\hline Hannover & 271800 & 268800 & 279900 & 820600 & 1.10 & 83600 & 904200 & 1.82 \\
\hline Göttingen & 157900 & 187100 & 204900 & 549900 & 1.08 & 42900 & 592800 & 6.77 \\
\hline Braunschweig & 35200 & 48200 & 124600 & 208000 & 1.07 & 13700 & 221700 & 1.89 \\
\hline Osnabrück & 23200 & 32200 & 147100 & 202400 & 1.05 & 10500 & 212900 & 2.68 \\
\hline Oldenburg & 27500 & 33200 & 97000 & 157700 & 1.06 & 9600 & 167300 & 2.31 \\
\hline Hildesheim & 8200 & 22700 & 64000 & 94900 & 1.04 & 4300 & 99200 & 1.32 \\
\hline Lüneburg & 6900 & 19500 & 57600 & 84000 & 1.04 & 3800 & 87800 & 1.82 \\
\hline Clausthal & 12000 & 18800 & 30500 & 61300 & 1.06 & 3700 & 65000 & 1.68 \\
\hline Wolfenbüttel & 5800 & 8200 & 34900 & 48900 & 1.06 & 3000 & 51900 & 2.15 \\
\hline Vechta & 3300 & 8800 & 29200 & 41300 & 1.05 & 1900 & 43200 & 0.73 \\
\hline Wilhelmshaven & 4100 & 6400 & 28400 & 38900 & 1.07 & 2600 & 41500 & 1.41 \\
\hline Emden & 4200 & 5000 & 26800 & 36100 & 1.05 & 1900 & 38000 & 1.07 \\
\hline Wolfsburg & 1700 & 1700 & 21200 & 24600 & 1.06 & 1500 & 26100 & 0.12 \\
\hline Lingen & 1600 & 4400 & 14200 & 20100 & 1.05 & 900 & 21000 & 0.16 \\
\hline Salzgitter & 1400 & 1800 & 15600 & 18800 & 1.06 & 1100 & 19900 & 0.39 \\
\hline Suderburg & 1200 & 2300 & 7700 & 11300 & 1.06 & 600 & 11900 & 0.49 \\
\hline Holzminden & 900 & 1600 & 7700 & 10200 & 1.06 & 600 & 10800 & 0.50 \\
\hline Buxtehude & 400 & 1600 & 5700 & 7600 & 1.03 & 200 & 7800 & 0.13 \\
\hline Elsfleth & 500 & 900 & 3800 & 5200 & 1.07 & 300 & 5500 & 0.18 \\
\hline Hameln & 300 & 1100 & 3100 & 4400 & 1.03 & 200 & 4600 & 0.09 \\
\hline Leer & 300 & 700 & 3100 & 4100 & 1.05 & 200 & 4300 & 0.09 \\
\hline Ottersberg & 200 & 500 & 3100 & 3800 & 1.05 & 100 & 3900 & 0.10 \\
\hline Diepholz & 200 & 400 & 1700 & 2400 & 1.04 & 100 & 2500 & 0.04 \\
\hline Lower Saxony & 1252200 & 879100 & 1435500 & 3566800 & 1.27 & 973800 & 4540600 & 1.64 \\
\hline Mean & 24730 & 29387 & 52687 & 106804 & 1.06 & 8143 & 114948 & 1.21 \\
\hline Min & 200 & 400 & 1700 & 2400 & 1.03 & 100 & 2500 & 0.04 \\
\hline $25 \%$-Quartile & 700 & 1600 & 6700 & 8900 & 1.05 & 450 & 9300 & 0.15 \\
\hline Median & 3300 & 5000 & 26800 & 36100 & 1.06 & 1900 & 38000 & 0.73 \\
\hline 75\%-Quartile & 10100 & 21100 & 60800 & 89450 & 1.06 & 4050 & 93500 & 1.82 \\
\hline Max & 271800 & 268800 & 279900 & 820600 & 1.10 & 83600 & 904200 & 6.77 \\
\hline
\end{tabular}

LC.M: Local consumption of material, LC.UP: Local private consumption of university personnel, LC.S: Local private consumption of students, TLC: Total local university-related consumption (direct effect), IM: Income multiplier, I.IE: Indirect income effect, TDE: Total demand effect (direct demand effect and indirect income effect), S.GDP: Share of the total demand effect in GDP. All values are given in thousand euros rounded to the nearest 100 except for the income multiplier and the percentage share.

Source: Statistisches Landesamt Niedersachsen (higher education statistics, different volumes), Statistisches Landesamt Niedersachsen (household budget survey, private household consumption expenditures in 2013 differentiated by the social status of the main income earner), Statistische Ämter des Bundes und der Länder (commuter statistics, employees subject to social insurance contributions at their place of work and of residence as well as commuting activities), Volkswirtschaftliche Gesamtrechnungen der Länder (Regional Accounts, gross domestic product and gross value added on NUTS 3 level for Germany); author's own calculations based on a regional input-output table (Stöver 2018). 
demand effects of between 2.4 million and 8.9 million euros and are mainly situated in the north.

The direct demand effects that can be assigned to the existence of the universities trigger indirect income effects ranging from 0.1 million euros in Diepholz (Landkreis Diepholz) to 83.6 million euros in Hannover (Region Hannover). As the interconnectedness of the universities with other local economic actors is assumed to be the same for all university locations, the regional disparities are also shown in the indirect effects. This means that while the median university location induces indirect income effects of 1.9 million euros, the mean value lies at 8.1 million euros and is mainly determined by the high values of Hannover (Region Hannover), Göttingen (Landkreis Göttingen), Braunschweig (kreisfreie Stadt Braunschweig), Osnabrück (kreisfreie Stadt Osnabrück) and Oldenburg (kreisfreie Stadt Oldenburg). The lower quartile generates less than 0.5 million euros indirect income with its local demand.

In total, the demand of an average university location leads to a direct and indirect effect of 114.9 million euros. The demand-side effects exhibit high spatial disparities with a minimum value of 2.5 million euros for Diepholz (Landkreis Diepholz) and a maximum value of 904.2 million euros for Hannover (Region Hannover). Again, the five university locations named above produce the highest effects with values ranging between the maximum value and 167.3 million euros in Oldenburg (kreisfreie Stadt Oldenburg). The university locations in the lowest quartile cause less than 9.3 million direct and indirect demand-side driven effects.

Nevertheless, even locations with lower demand effects than the other university locations can be of higher importance for their region if the demand effects make a major contribution to overall local economic performance. The university location Wolfenbüttel (Landkreis Wolfenbüttel), for example, ranks ninth regarding total demand effects in comparison to the other university locations. With a value of 51.9 million euros the total demand effect is above the median but below the upper quartile and the mean value. In relation to the local economic structure the total demand effects contribute a share of $2.2 \%$ to GDP. This proportion is much higher than in many other university locations as it is a value in the upper quartile and almost one percentage point above the average. The demand-side contribution of the university location Wolfenbüttel (Landkreis Wolfenbüttel) is hence more important for its region itself than that of other university contributions. The university location Elsfleth (Landkreis Wesermarsch) also manages to improve in terms of the quartiles when the relative value of the contribution is assessed: while the absolute total demand effect of 5.5 million euros is below the lower quartile the contribution to local GDP is $0.2 \%$, a value above the lower quartile. The university location is thus of comparably higher importance for its local economy.

Only one university location is more important in the university context than in their own local context: the university location Wolfsburg (kreisfreie Stadt Wolfsburg) accounts for a total demand effect of 26.1 million euros, representing $0.1 \%$ of local GDP. While the demand-side contributions are above the lower quartile compared to the other university locations, local importance only reaches a value below the lower quartile.

Overall, the spatial distribution in the left-hand map of Figure 3 shows that the university locations in the southeast of Lower Saxony are more successful in generating large demand effects. In contrast, the smallest demand effects can be found in the mid-northern part of Lower Saxony. With regard to the spatial distribution of local importance on the right-hand side of Figure 3 the picture is no longer that clear-cut, but the north-south divide is still noticeable.

The regional disparities of the demand effects are also seen with the employment effects (see Table 2 and Figure 4). Large total employment effects can be mainly assigned to the south-east with maximum employment in Hannover (Region Hannover). The smallest impacts with less than 200 direct and indirect jobs are mainly generated in the northern parts of Lower Saxony. ${ }^{20}$

In summary, the demand of all university locations together causes direct and indirect effects of 4,541 million euros, contributing $1.6 \%$ to GDP in Lower Saxony. ${ }^{21} 3,567$ million euros result from the direct demand effects of the university locations, 974 million euros arise indirectly from the income effects. With regard to employment, the almost 57,000 direct jobs in universities lead to about an additional 18,000 jobs so that university locations directly and indirectly account for almost 70,000 jobs in Lower Saxony. This represents $1.7 \%$ of the labour market in Lower Saxony. The direct and indirect effects are not uniformly distributed in Lower Saxony. Rather, spatial disparities of a north-south divide can be identified.

20 Due to space limitations the results for the employment effects are not further discussed.

21 The total demand effect is not equal to the sum of the local demand contributions of each university location. Due to the underlying assumption regarding the local part of the consumption, consumption expenditures from university personnel or students that were spent in a neighbouring university location would not be considered in a simple summation. Therefore, the contribution on NUTS 1 level was calculated separately. 


\section{Total demand effect (2016)}

Euro, thousand

2,500 to 9,300

9,300 to 38,000

38,000 to 93,500

93,500 to 904,200

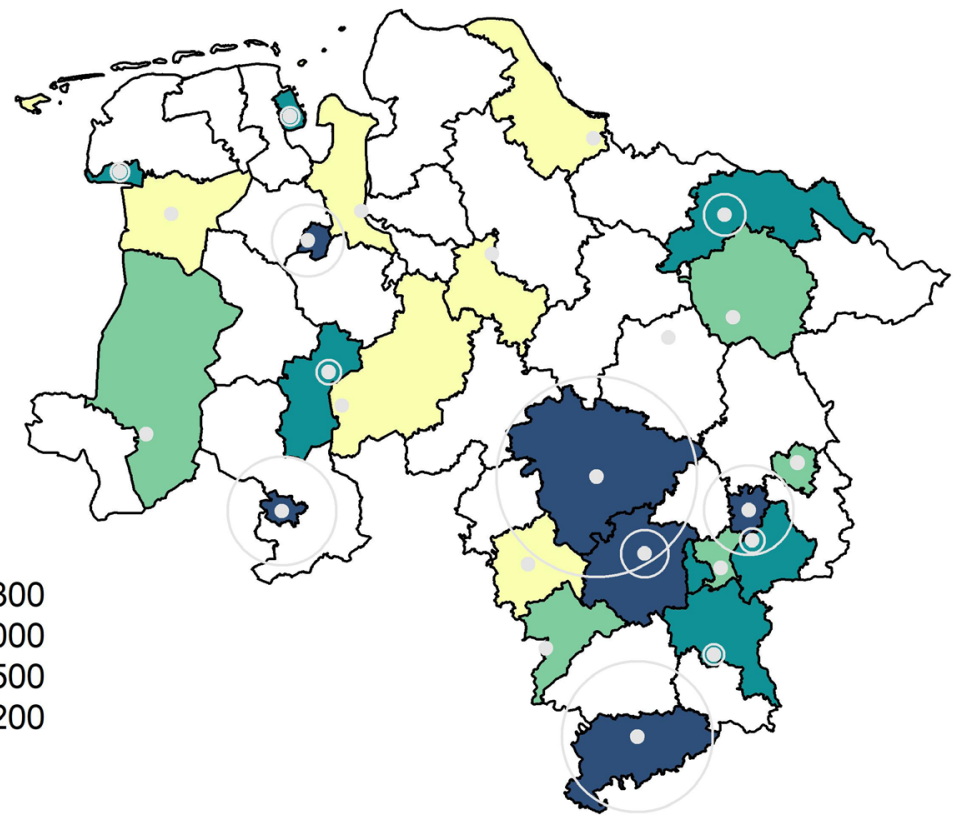

Share in GDP (2016)

Share in GDP (\%)
0.04 to 0.15
0.15 to 0.73
0.73 to 1.82
$-\quad 1.82$ to 6.77

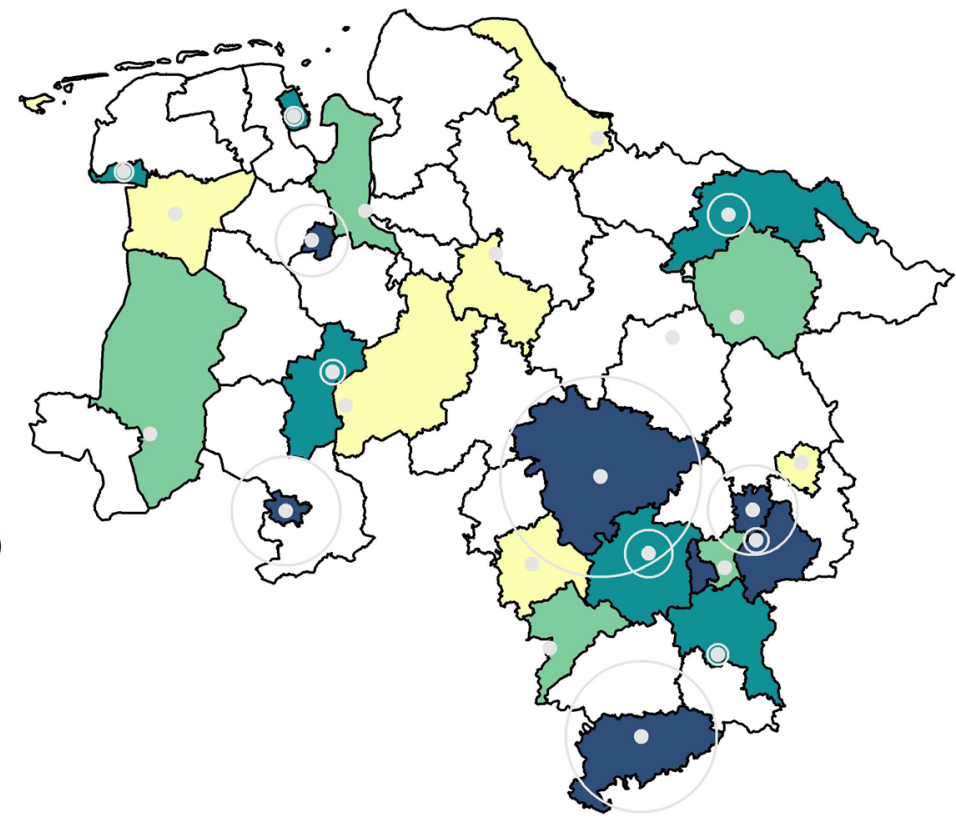

Figure 3: Total demand effect and share in local GDP (2016)

Note: The NUTS 3 regions in white represent regions without university locations and are not the focus of this analysis. However, although they are not coloured, this does not imply that positive spillovers from the university locations could not arise. Rather, the part of the consumption that is not locally consumed within the university location (e.g. due to commuting and holidays) would partially affect the neighbouring regions, although this is not further considered in this analysis. The spillover effects become only indirectly apparent in the total values on NUTS 1 level for Lower Saxony.

Source: Statistisches Landesamt Niedersachsen (higher education statistics, different volumes), Volkswirtschaftliche Gesamtrechnungen der Länder (Regional Accounts, gross domestic product and gross value added on NUTS 3 level for Germany); author's own calculations based on a regional input-output table (Stöver 2018). Map: GADM data, Version 2.8. 
Table 2: Direct employment and indirect demand-related employment effects (in number of persons)

\begin{tabular}{|c|c|c|c|c|c|}
\hline University location & E.UP & E.Ind & TEE & EM & S.LM \\
\hline Hannover & 17440 & 2730 & 20170 & 1.16 & 3.00 \\
\hline Göttingen & 13230 & 1560 & 14800 & 1.12 & 10.63 \\
\hline Braunschweig & 4440 & 410 & 4850 & 1.09 & 2.96 \\
\hline Osnabrück & 4140 & 240 & 4380 & 1.06 & 3.46 \\
\hline Oldenburg & 3400 & 270 & 3670 & 1.08 & 3.20 \\
\hline Hildesheim & 2080 & 90 & 2170 & 1.04 & 1.73 \\
\hline Lüneburg & 1570 & 80 & 1650 & 1.05 & 2.00 \\
\hline Clausthal & 1150 & 110 & 1260 & 1.10 & 2.04 \\
\hline Wolfenbüttel & 800 & 60 & 860 & 1.07 & 2.31 \\
\hline Vechta & 740 & 40 & 780 & 1.05 & 0.84 \\
\hline Emden & 630 & 40 & 670 & 1.06 & 1.59 \\
\hline Wilhelmshaven & 530 & 50 & 570 & 1.09 & 1.27 \\
\hline Lingen & 380 & 20 & 390 & 1.04 & 0.21 \\
\hline Wolfsburg & 240 & 20 & 260 & 1.07 & 0.20 \\
\hline Salzgitter & 200 & 10 & 210 & 1.07 & 0.37 \\
\hline Suderburg & 170 & 10 & 180 & 1.07 & 0.43 \\
\hline Holzminden & 160 & 10 & 160 & 1.06 & 0.52 \\
\hline Buxtehude & 110 & 0 & 120 & 1.04 & 0.13 \\
\hline Hameln & 100 & 0 & 110 & 1.03 & 0.16 \\
\hline Ottersberg & 100 & 0 & 100 & 1.03 & 0.16 \\
\hline Elsfleth & 60 & 10 & 70 & 1.09 & 0.18 \\
\hline Diepholz & 60 & 0 & 60 & 1.04 & 0.06 \\
\hline Leer & 50 & 0 & 50 & 1.06 & 0.07 \\
\hline Lower Saxony & 51780 & 17930 & 69710 & 1.35 & 1.74 \\
\hline Mean & 2251 & 250 & 2502 & 1.07 & 1.63 \\
\hline Min & 50 & 0 & 50 & 1.03 & 0.06 \\
\hline 25\%-Quartile & 135 & 10 & 140 & 1.05 & 0.19 \\
\hline Median & 530 & 40 & 570 & 1.06 & 0.84 \\
\hline $75 \%$-Quartile & 1825 & 100 & 1910 & 1.08 & 2.18 \\
\hline Max & 17440 & 2730 & 20170 & 1.16 & 10.63 \\
\hline
\end{tabular}

Note: E.UP: University personnel, E.Ind: Indirect employment, TEE: Total employment effect (direct and indirect employment effect), EM: Employment multiplier, S.LM: Share of the total employment effect in the total labour market. All values are given in number of persons rounded to the nearest 10 except for the employment multiplier and the percentage share.

Source: Statistisches Landesamt Niedersachsen (higher education statistics, different volumes), Statistisches Landesamt

Niedersachsen (household budget survey, private household consumption expenditures in 2013 differentiated by the social status of the main income earner), Volkswirtschaftliche Gesamtrechnungen der Länder (Regional Accounts, gross domestic product and gross value added on NUTS 3 level for Germany); author's own calculations based on a regional input-output table (Stöver 2018). 
Total employment effect (2016)

Persons

50 to 140

140 to 570

- 570 to 1,910

- 1,910 to 20,170

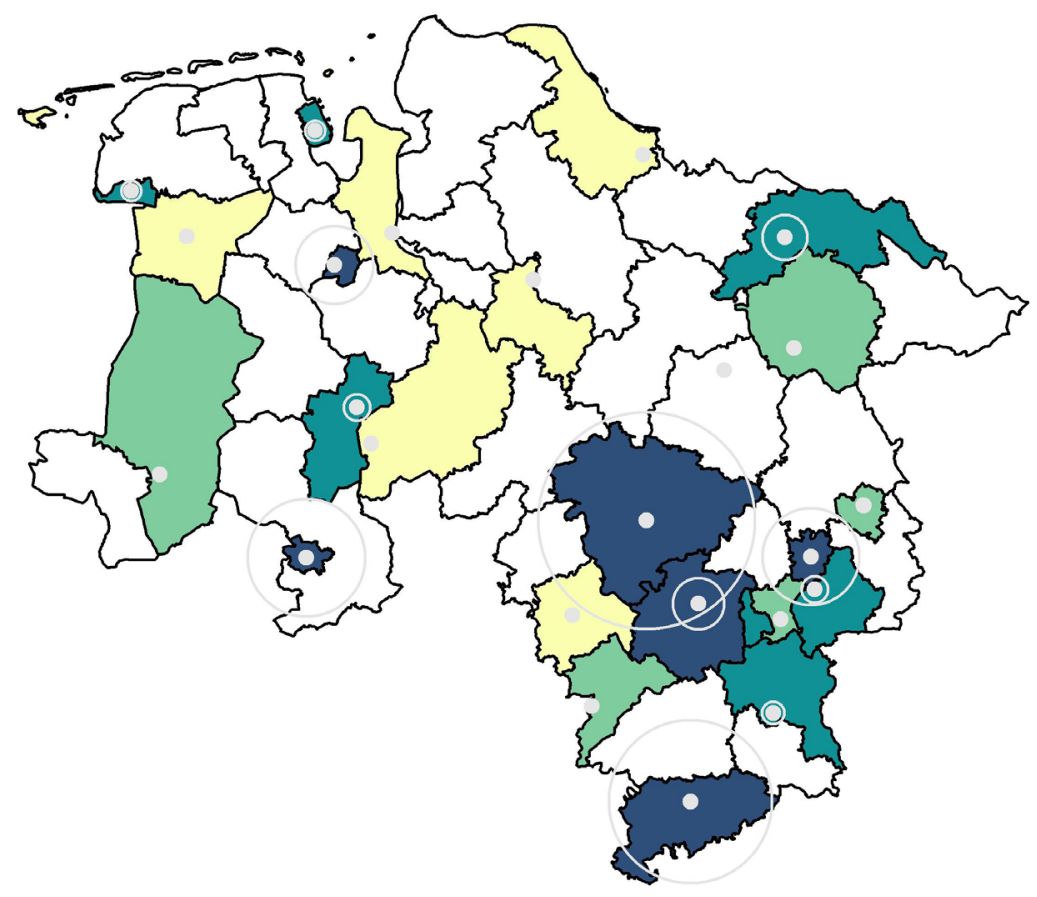

\section{Share in labour market (2016)}

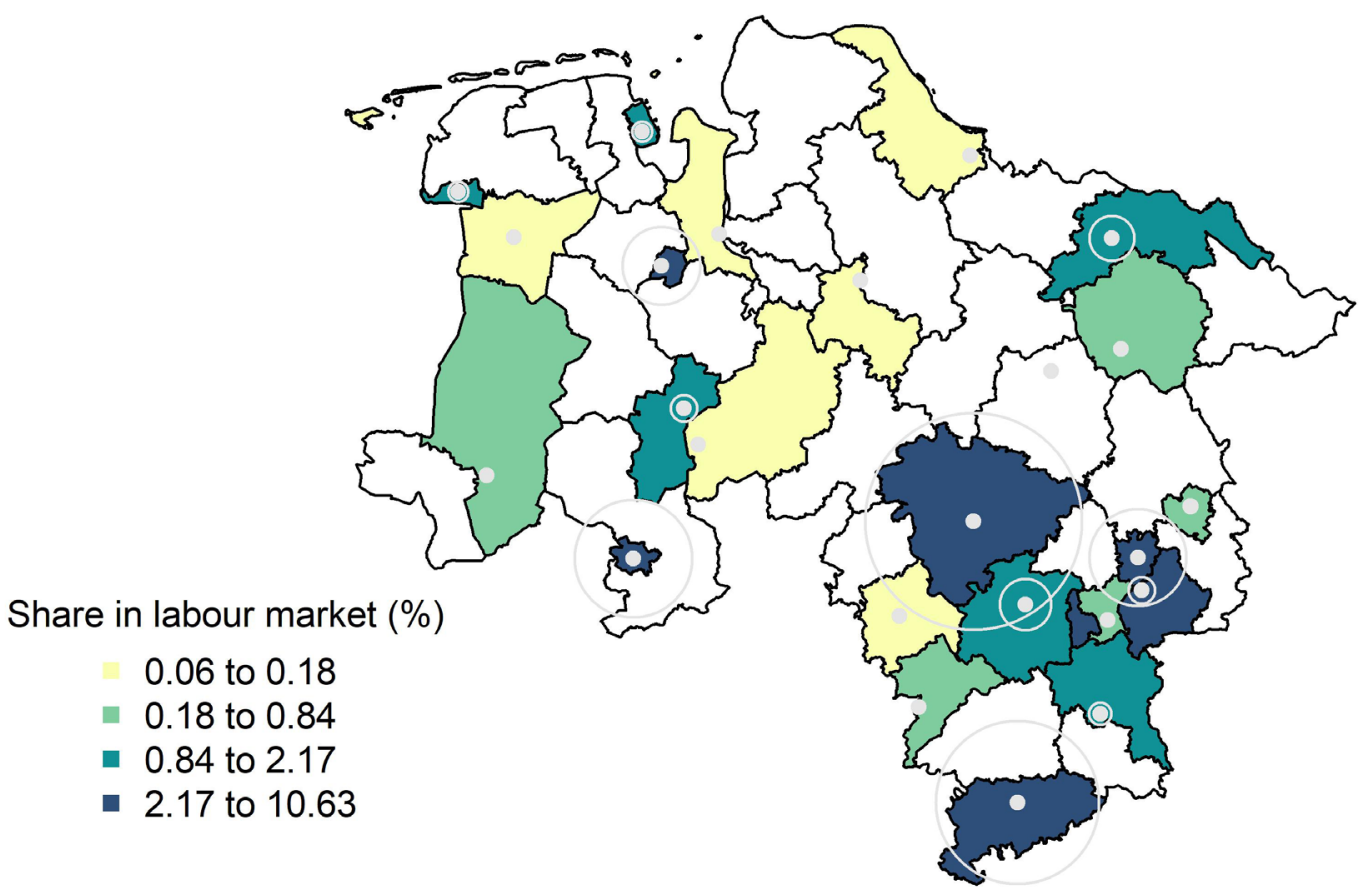

Figure 4: Total employment effect and share in the local labour market (2016)

Source: Statistisches Landesamt Niedersachsen (higher education statistics, different volumes), Volkswirtschaftliche Gesamtrechnungen der Länder (Regional Accounts, gross domestic product and gross value added on NUTS 3 level for Germany); author's own calculations, based on a regional input-output table (Stöver 2018). Map: GADM data, Version 2.8. 


\section{The supply-side contributions of the university locations}

In contrast to the demand-side effects, the impact and contribution of the output of universities is not easily and directly measurable in monetary terms (Glückler/Panitz/ Wuttke 2015: 329). The supply-side effects (often also classified as medium- to long-term effects) arise from the generation of knowledge, the qualification of the labour force, the transfer and distribution of knowledge, the facilitation and generation of technical innovation, the development and establishment of knowledge infrastructure, participation in political and civic decisionmaking processes and the creation of an environment favourable for intellectual, cultural, ethical and creative impulses (Glückler/Panitz/Wuttke 2015: 329). The latter, i.e. household-related infrastructure influencing and enhancing socio-cultural activities and quality of life, are only indirect outputs and almost not quantifiable. They are not part of the following estimation of the supply-side effects.

A theoretical basis for the positive impact of the supply-side effects of universities in educating students and doing research is deduced from endogenous growth theory as introduced by Romer (1986) and Lucas (1988): the accumulation of human capital through education and its dispersion through knowledge spillovers lead to innovation and higher economic growth.

\subsection{Measuring the supply-side contributions}

Human capital theory introduced by Schultz (1963) and Becker (1964) and the theory of investment in human capital proposed by Mincer (1974) constitute the positive relationship between education and economic growth or income respectively. This provides the basis for the assumption that a highly educated workforce is more productive. Employees with higher education are assumed to adapt more easily to new production facilities or find new and more efficient ways of production (e.g. Bartel/Lichtenberg 1987). They are more likely to invent new products (e.g. Lucas 1988; Romer 1990; Barro/Salai-Martin 2003) or to start a business (e.g. Fritsch 2011), and their wages and salaries are higher (e.g. Krueger/ Lindahl 1999). Taken overall, the positive effects of higher education support economic growth.

There are several critiques which state that education alone is not sufficient for the accumulation of human capital and hence the positive impact on economic growth. Additional factors that also play an important role are family background and the related appreciation of education (Bourdieu 1979; Kellaghan/Sloane/Alvarez et al. 1993; Fuller/Clarke 1994; Wößmann 2003) as well as social conditions such as social capital and values and norms (Coleman 1988; Putnam 2000).

Nevertheless, a variety of empirical studies confirm the direct positive relationship between human capital, income and economic growth. A summary provided by Psacharopoulos and Patrinos (2004) gives an overview of the empirically measured returns to education that support the existence of a positive relationship between education and income, implying that university graduates can expect a higher level of income. In "The Well-being of Nations" (OECD 2001) the results of empirical studies measuring the direct effect of education on economic growth is discussed. The main conclusion (OECD 2001: 31) derived from Nehru, Swanson and Dubey (1995) and Temple (2001) is that human capital has a substantial and positive impact on growth of GDP or income per capita and that especially more recent research provides evidence of the positive effects of education.

The effect of the university locations' output in Lower Saxony was estimated referring to human capital theory and the existing empirical findings. In the estimation function, local GDP depends on the number of graduates (representing the universities' education output). The related coefficient is supposed to be positive.

Technological innovation depends on the combination of relevant regional circumstances and conditions such as organisational networks of innovators, regional innovation complexes and regional knowledge infrastructure (Anselin/Varga/Acs 1997: 423). Universities are one main factor in the innovation generation process. University research is seen to be important for the development of new knowledge and technologies as well as for the broadening of the knowledge base and its diffusion. Additionally, educated university graduates apply their acquired knowledge on the job, introducing new ideas, concepts and procedures into companies. Overall, such positive university-driven innovation externalities can be interpreted as knowledge spillovers from universities to the private sector. This line of argumentation was first introduced by Nelson (1959) and Arrow (1962).

Many empirical studies have investigated the innovation spillovers arising from universities, confirming a positive relationship between the number of universities or university-company networks and innovations represented by the number of patents (e.g. Jaffe 1989; 
Mansfield 1991; Anselin/Varga/Acs 1997; Anselin/Varga/ Acs 2000; Varga 2006; Criscuolo/Haskel/Slaughter 2010).

The influence of universities on innovation is hence estimated in this paper, assuming a positive relationship between the number of patents and university-related research values. The explanatory variables encompass the number of university personnel, the number of students differentiated by area of study, the number of university graduates and the amount of third party funds. A higher number of university employees is supposed to have a positive impact on innovation as more resources can be dedicated to research. However, during the estimation process a differentiation between scientific and non-scientific personnel proved to be useful, with only the non-scientific personnel showing a significant negative effect. The line of argumentation is that university locations with a high number of administrative employees are less involved in research and should hence exhibit less knowledge externalities. The number of students by area of study represents the relative importance of research intensive areas (such as medicine and engineering) at the university location and the probability of local research clusters with high knowledge spillovers. The number of graduates is supposed to serve as an indicator of the spillovers arising through knowledge transfer. Third party funds are assumed to display how much effort is placed in conducting additional research projects.

The impact of university locations on GDP and patents is estimated using the R-package splm for spatial panels (Millo/Piras 2012). The estimation equation for the dependent variables GDP and patents represented by $y$ is:

$$
\begin{aligned}
& y=\lambda\left(I_{T} \otimes W_{N}\right) y+X \beta+\left(\iota_{T} \otimes I_{N}\right) \mu+ \\
& +\left(\iota_{T} \otimes D_{N}\right) \alpha_{c l}+\rho\left(I_{T} \otimes W_{N}\right) v+\varepsilon
\end{aligned}
$$

with $I_{T}$ and $I_{N}$ being an identity matrix of dimension $T \times$ $T$ and $N \times N$ respectively and $I_{T}$ being a vector of one with dimension $T \times 1$. $W_{N}$ is the spatial weights matrix with dimension $N \times N$ and $\lambda$ the spatial autoregressive parameter (spatial lag). $X$ with dimension $N T \times K$ consists of the $K$ explanatory variables, $\beta$ are the $K$-related coefficients. $\mu$ represents the time-invariant individual specific effects $(N \times 1)$ and $\alpha$ the cluster-specific fixed effects of cluster $\mathrm{Cl}=1, \ldots, 4$. The error term consists of a spatial autoregressive process with the spatial autoregressive parameter (spatial error) $\rho$ and a wellbehaved error term $\varepsilon$.
The explanatory variables in the estimation equation are complemented by control variables consisting of the migration balance of 25 to 30 year olds, the labour force, the percentage of (self)employed persons in the manufacturing sector, and the percentage of (self) employed in the agricultural sector. The first control variable is an indicator for the mobility of young people and the attractiveness of the respective region for the younger labour force. The second control variable, labour force, represents the sheer magnitude of the local labour market. The percentage of (self)employed persons in the manufacturing sector shows the importance of the high technology sector in the region. The last control variable is a measure for rurality.

In addition to the control variables cluster variables were added. They are intended to show universityspecific effects that would normally be hidden in the time-invariant individual specific effects. ${ }^{22}$ In order to keep the number of coefficients as low as possible the university locations are grouped in clusters. The clusters are determined using the k-means method. The variables that are relevant for the determination of the clusters are university personnel, university expenditures, university investment, students, university graduates and third party funds. ${ }^{23}$

The evaluation values suggest a differentiation of the university locations into four clusters with three, two, three and 15 university locations. Figure 5 shows the spatial distribution of the clusters. Cluster 2 consists of the two very large university locations Hannover (Region Hannover) and Göttingen (Landkreis Göttingen) where a lot of traditional and old universities can be found. Cluster 1 consists of large university locations that are represented by the cities (kreisfreie Stadt) Osnabrück, Oldenburg and Braunschweig. The university locations of Cluster 1 are on average half the size of the Cluster 2 university locations with regard to the number of students. The university locations of Cluster 3 are even smaller, reaching only $21 \%$ of the size of Cluster 2 . These medium-sized locations in Clausthal (Landkreis Goslar), Hildesheim (Landkreis Hildesheim) and Lüneburg (Landkreis Lüneburg) are situated in rather rural areas. Cluster 4 is characterised by very small university locations which often cooperate in partnerships to generate economies of scale. They do not even reach a tenth of the size of Cluster 2 locations.

22 The time-invariant individual effects drop out when estimating a panel with fixed effects due to the demeaning process.

23 Standardised mean values of the years 2010-2016 were used. 


\section{University cluster}

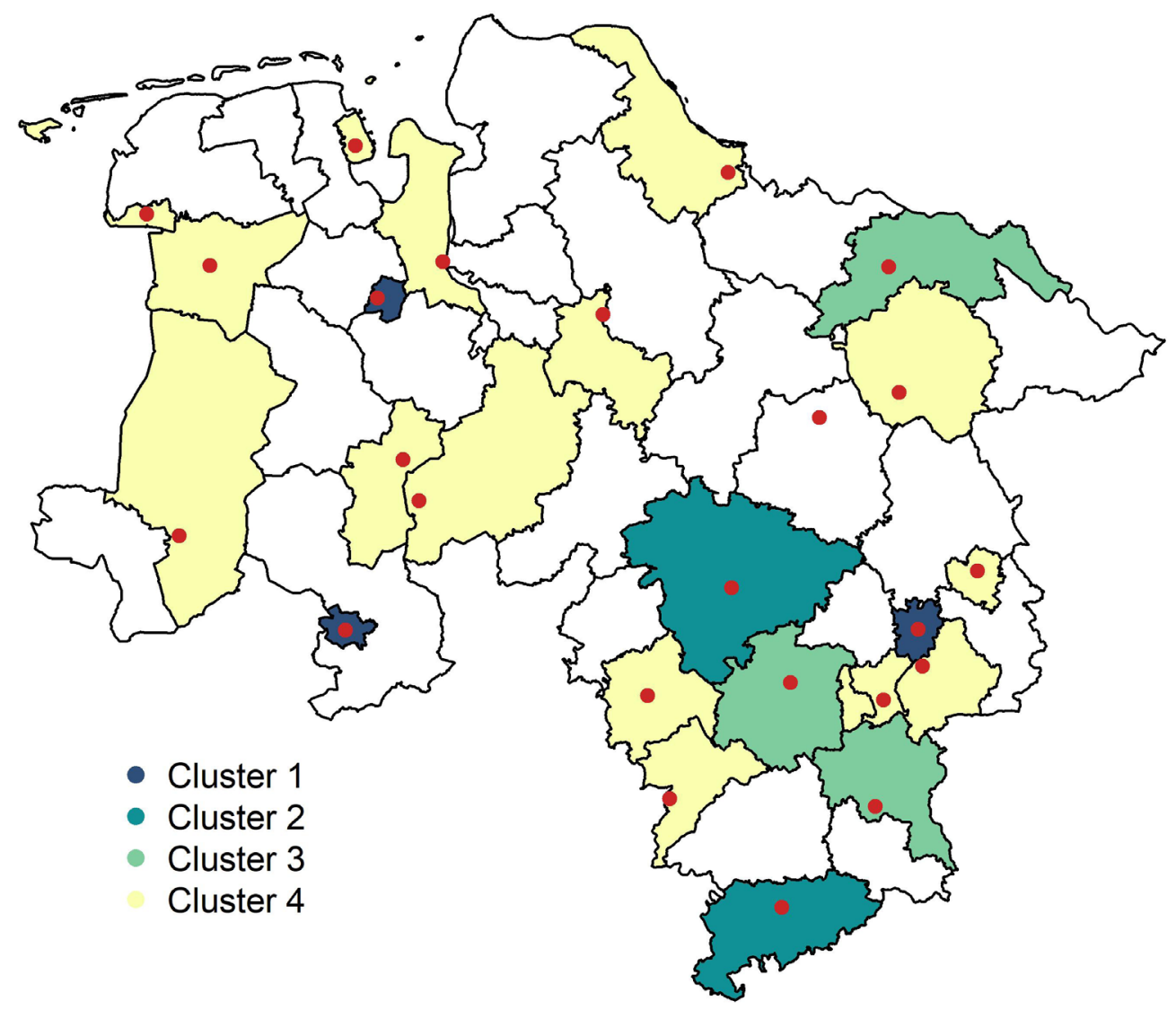

Figure 5: Local distribution of university cluster types

Source: author's own calculations. Map: GADM data, Version 2.8.

The spatial weights matrix consists of rowstandardised contiguity weights. The definition of neighbours depends on the one hand on the queen method and on the other hand on the existence of a university location. This means that neighbours are only linked with each other if at least one of the neighbours is a university location.

During the estimation process all variables were excluded that did not show any significance, i.e. that did not add to the explanation of the dependent variable. Spatial panel estimation was used as the NUTS 3 regions influenced each other. The interrelation could be found in the dependent variable (the spatial lag) as well as in the errors. Thus, the spatial interaction was taken into account to ensure a consistent, unbiased estimation of the parameters and errors. Due to the result of the spatial Hausman test, fixed effects were applied.

\subsection{Results of the supply-side contributions}

The regression results for economic growth in Table 3 confirm the positive relationship between the number of university graduates and the size of GDP. Thus, the results are in line with the empirical findings summarised in OECD (2001). An increase in human capital by one graduate per 100 inhabitants - leaving everything else unchanged and not considering the second round spillover effects due to the spatial lag in GDP - leads to an increase in GDP of 5,550 euros per capita. ${ }^{24}$

24 The coefficient value of Table 4 was converted to a more realistic unit. The mean value of graduates lies at 0.003 persons per capita so that a one-unit increase is very unlikely. Converting the values to one graduate per 100 inhabitants would represent a much more probable increase. 
Table 3: Regression results for GDP

\begin{tabular}{|c|c|c|c|c|}
\hline & Estimate & Std. Error & t-value & $\operatorname{Pr}(>|t|)$ \\
\hline Lambda (spatial lag) & $-0.249^{* * *}$ & 0.063 & -3.986 & 0.000 \\
\hline Rho (spatial error) & $0.249^{* *}$ & 0.086 & 2.909 & 0.004 \\
\hline University graduates & $555018^{\star *}$ & 208138 & 2.667 & 0.008 \\
\hline Net migration (25-30 year-olds) & $1197225^{*}$ & 466443 & 2.567 & 0.010 \\
\hline Share of manufacturing industry in total employment & $1367^{* \star *}$ & 80 & 17.135 & 0.000 \\
\hline Share of agriculture in total employment & $-1506^{* * *}$ & 291 & -5.175 & 0.000 \\
\hline University Cluster 1 & 6049 & 4766 & 1.269 & 0.204 \\
\hline University Cluster 2 & 4147 & 3895 & 1.065 & 0.287 \\
\hline University Cluster 3 & $-7236^{*}$ & 2842 & -2.547 & 0.011 \\
\hline University Cluster 4 & 2115 & 1488 & 1.422 & 0.155 \\
\hline R-Squared: 0.69 & \multicolumn{4}{|c|}{${ }^{*} p \leq 0,05,{ }^{* *} p \leq 0,01,{ }^{* * *} p \leq 0,001$} \\
\hline
\end{tabular}

Most interestingly however, the university locations do not exhibit significant positive effects on GDP. Though they are directly responsible for the number of university graduates as an output of the education process and the local concentration of this output should suggest a higher accumulation of human capital and hence a higher positive impact on local GDP, the positive relationship for university locations of Clusters 1, 2 and 4 is the same as for regions without university locations. This means that the university locations of Clusters 1, 2 or 4 do not differ from other regions and cannot notably take advantage of their education output. Even worse, the university locations of Cluster 3, i.e. Clausthal (Landkreis Goslar), Hildesheim (Landkreis Hildesheim) and Lüneburg (Landkreis Lüneburg) have a negative coefficient indicating that the positive impact of the universities on GDP here is smaller than in regions without universities.

This implies that the positive impact of accumulating human capital does not necessarily coincide with the location where human capital is created. The failure to locally internalise the education output suggests that the mobility of graduates is very high and that the good job markets are not necessarily at the university location. As the university locations of Cluster 3 are characterised by rurality, job opportunities are likely to be small at these locations. It is probable that a disproportionately high number of graduates hence leave these university locations so that the related regions are not able to internalise the positive educational effects.

Consequently, the size of the regional supply-side effects of the education output is less characterised by differences between university locations and more by labour market disparities. Thus, regional universityrelated patterns cannot be identified (see Figure 6).

The positive relationship between the researchrelated output of universities and innovation suggested by Nelson (1959) and Arrow (1962) can be confirmed by the regression results. The general impact on innovation, i.e. the effects that arise out of the factors related to knowledge and research for all regions within Lower Saxony irrespective of whether they have a university or not, depends on the characteristics and the focus of the university locations.

An increase in non-scientific personnel by one person per 100 inhabitants c.p. would reduce the number of patents by 8.8 per 100 inhabitants in Lower Saxony. This means that a general shift in interest away from research has a negative impact on the overall amount of innovation within the country. The overall mix of the scientific subjects offered at all university locations together shows contrasting effects on the number of patents depending on the focus. While a trend towards medical sciences (represented by an increase in students in this field) leads to a higher number of patents, the relationship between arts and patents is the other way round. Medical sciences are expected to be more involved in applied research, implying a higher output of new products, applications and ideas to file for patents. In contrast, arts disciplines are not associated with applied research, as is reflected by the negative sign of the coefficient. The general acquisition of third party funds affects the number of patents positively, albeit at a 


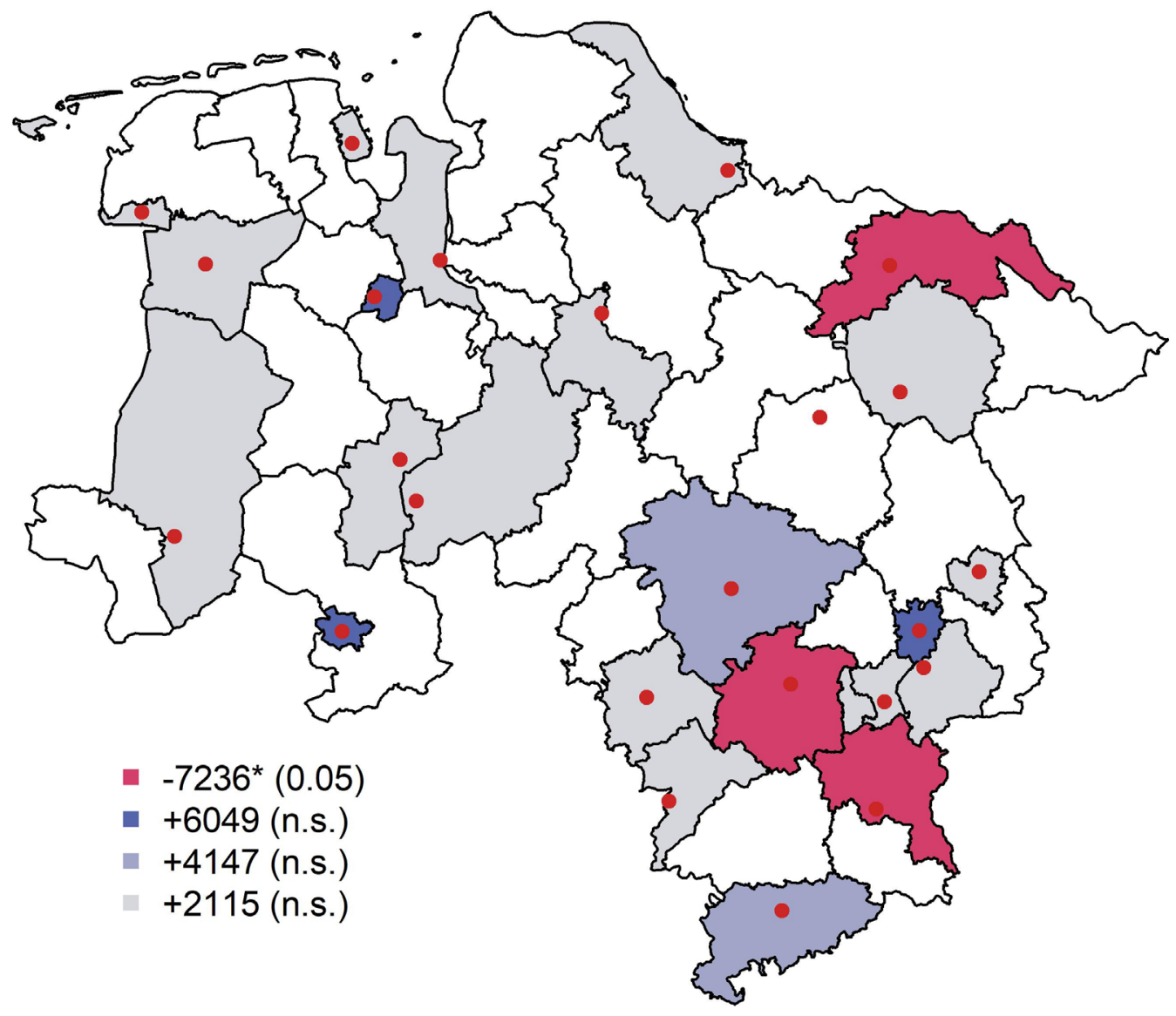

Figure 6: Impact of university locations on regression coefficients for GDP

Source: author's own regression results. Map: GADM data, Version 2.8.

very low level. One extra euro per 1,000 inhabitants will result in a plus of 0.001 patents per 1,000 inhabitants.

Most importantly, spatial proximity to a university is significantly relevant and supports the positive effects on innovation. This is in line with the empirical findings of e.g. Jaffe (1989) or Varga (2006) who state that distance to the university matters. In the results this is expressed by the positive coefficients related to the university locations of Clusters 1, 2 or 4. The positive impact on innovation is higher for a university location of Clusters 1,2 or 4 than for a region without a university. Moreover, the additional positive effects are highest for university locations concentrated in a city (kreisfreie Stadt Osnabrück, Oldenburg and Braunschweig) followed by the very big university locations Hannover (Region Hannover) and Göttingen (Landkreis Göttingen). But even the smallest university locations of Cluster 4 still generate higher positive effects on innovation than regions without universities. Only the university locations of Cluster 3 cannot generate extra effects compared to regions without a university.

Finally, the spatial lag was excluded due to insignificance. The spatial effects only emerged in the error term, so that the generation of patents seems to be a more local process.

In summary, the spatial proximity between universities and companies seems to positively affect the possibility for knowledge spillovers to positively result in more innovation. The most relevant and influential university locations are those in cities or those of extreme size. As displayed in the map of Figure 7, such locations are mainly found in the south of Lower Saxony. The main area of innovation can hence be assigned to the southern part of Lower Saxony, adding to the spatial disparities found for the demand-side contributions. 


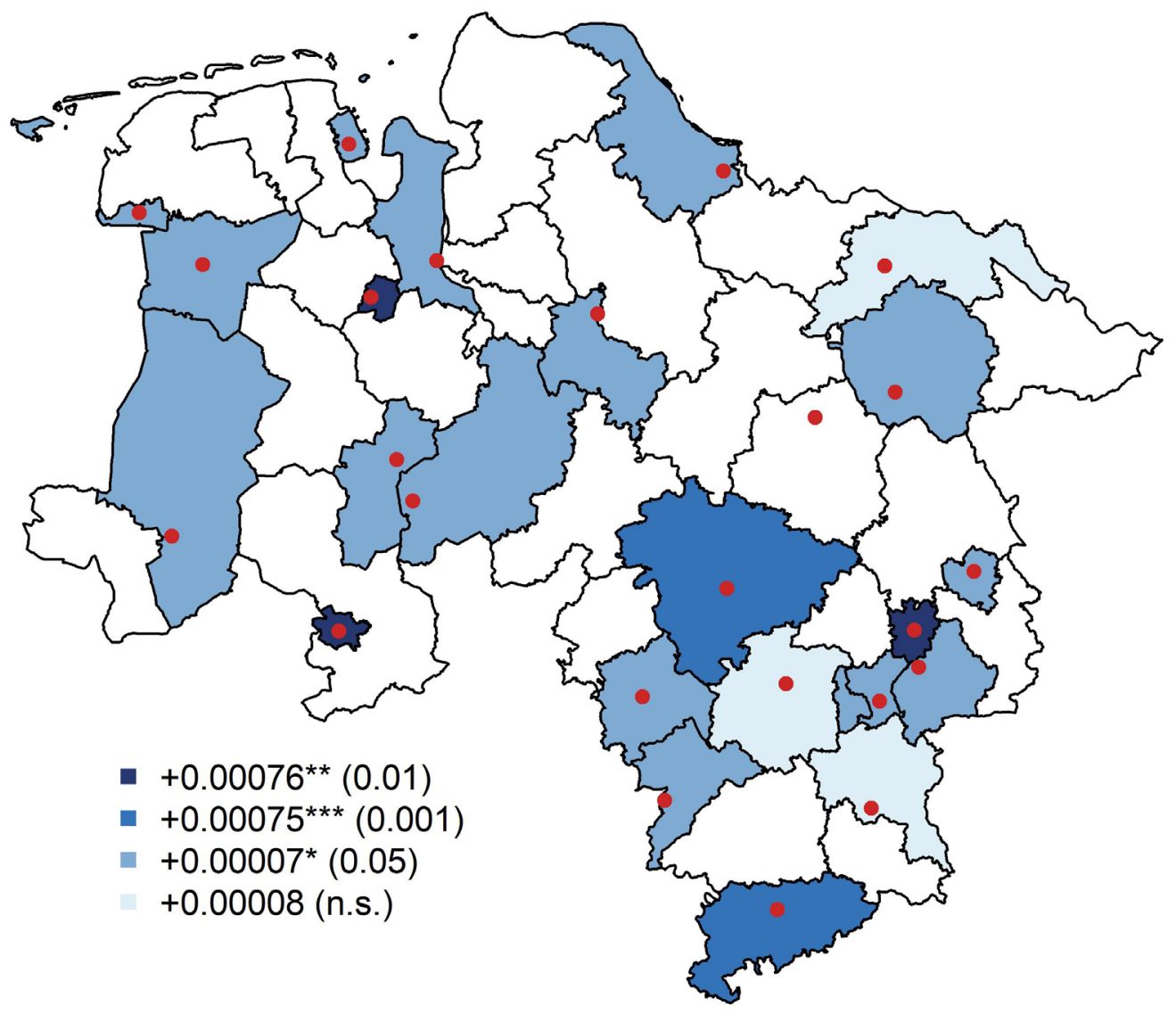

Figure 7: Impact of university locations on regression coefficients for patents Source: author's own regression results. Map: GADM data, Version 2.8.

\section{Conclusion}

The estimation results give an impression of the economic importance and the size of the demand- and supply-side effects of university locations in Lower Saxony and help to identify regional patterns or spatial disparities.

On the demand side, university locations contribute up to $6.8 \%$ to local GDP or up to $10.6 \%$ to local employment. The highest positive effects with values over the median are mainly generated in the south of Lower Saxony while the northern locations are more characterised by contributions below the lowest quartile. The university locations can be of higher importance in relation to their own local situations, but the overall effect of the spatial disparity still remains.

On the output side, the north-south divide is not as pronounced as for the demand side. Especially the results for human capital accumulation as represented by graduates suggest that the situation is rather one of competition between the labour markets of university and non-university regions: all regions within Lower Saxony seem to profit equally from the education output provided they have jobs to offer. The graduates seem to be very flexible and to move to regions with attractive job markets. This does not necessarily coincide with the university location no matter the size. But it leads to university locations in rural areas being worse off than all other regions: they cannot internalise their human capital due to structural weaknesses and a lack of job opportunities. With regard to innovation, regions with a university can profit from the research activities and knowledge spillovers. The effects are highest in the big and very big university locations mainly situated in the southern parts of Lower Saxony. Nevertheless, there is also a need for companies and a willingness to cooperate. Here the regions with university locations in rural areas are not more innovative than other regions without universities.

Taken together, the results suggest at first glance that small university locations, especially in more rural 
and structurally weak regions, are of lower importance. But, as Schamp and Bathelt (2002: 1) state, universities always positively affect their region through their mere existence and size as organisations. Additionally, even small university locations can be of enormous local importance if they have close relationships with the local economy, whether in terms of demand for goods and services or in terms of co-operation in knowledge networks. Close relationships with local companies offer graduates greater job opportunities so that they have more incentive to stay in the region after their degrees, leading to the accumulation of knowledge, the regional internalisation of human capital and the possible generation of growth impulses (Assenmacher/Leßmann/ Wehrt 2004: 96; Gries 1995). Moreover, though not included in the estimations of this study, the students and their leisure activities might ensure the existence of pubs, restaurants, supermarkets, cinemas etc., thereby improving the living conditions for all local inhabitants.

However, the integration of the university in the region and especially co-operation with local companies mainly depends on intensive personal contacts and the engagement of personnel from the university as well as the companies (Blume/Fromm 2000: 55). The positive supply effects caused by the presence of a university will only occur with a mutual willingness to cooperate. Policy measures can support this through the allocation of grants.

Finally, Blume and Fromm (2000: 110) point out that the primary function of universities is still the supply of a non-material public good, that is to say the generation of knowledge and the education of students, and not the pecuniary maximisation of the positive output effects.

With regard to the methodology, some critical remarks have to be made. Though the demand-side effects appear to be exact results, a lot of assumptions had to be made during the calculation process, leading to statistical imprecision and uncertainties. Thus, the estimated direct and indirect effects should primarily give an impression of the importance and the contribution of university locations. One critical assumption results from the regional multipliers based on the input-output table: due to data availability it had to be assumed that the import shares of the main input coefficients (of production) are the same for all university locations, implying that the indirect employment and income effects are quite similar for each location. University locations that are more integrated in the economic structure of their region and hence import less from outside the region would normally show higher indirect effects. Together with the fact that investment is excluded from the impact assessment the demand-side results can be interpreted as conservative, meaning that the positive effects are likely to be even higher.

With regard to the supply-side effects it has to be noted that social factors such as family and social background are not included in the estimation function. Social factors are assumed to influence the generation and successful distribution of human capital as well. Lucas (1988: 19) states that human capital accumulation is a social activity as household members have to pass on their knowledge in order to increase the household's stock of human capital. Positive social effects might therefore be captured by the other regression coefficients so that the impact of the university locations might be overstated.

Taken overall, the results are important in that they give a complete picture of the importance and significance of the different university locations within Lower Saxony on a disaggregated spatial level using consistent data sets and methodologies. In a next step, the results could be used to evaluate funded projects that aim to intensify the co-operation of universities with local companies or that are supposed to promote networks. Additionally, universities can be identified that might especially profit from structural funds to strengthen their economic importance in the region and their positive impact.

\section{References}

Anselin, L.; Varga, A.; Acs, Z. (1997): Local Geographic Spillovers between University Research and High Technology Innovations. In: Journal of Urban Economics 42, 3, 422-448. doi: 10.1006/juec.1997.2032

Anselin, L.; Varga, A.; Acs, Z. (2000): Geographical Spillovers and University Research: A Spatial Econometric Perspective. In: Growth and Change 31, 4, 501-515. doi: 10.1111/0017-4815.00142

Arrow, K.J. (1962): Economic Welfare and the Allocation of Resources for Invention. In: National Bureau of Economic Research (ed.): The Rate and Direction of Inventive Activity: Economic and Social Factors. Princeton, 609-626.

Assenmacher, M.; Leßmann, G.; Wehrt, K. (2004): Regionale Entwicklungsimpulse von Hochschulen. Einkommens-, Beschäftigungs- und Kapazitätseffekte der Hochschulen Anhalt und Harz $(\mathrm{FH})$. Wernigerode.$=$ Harzer Hochschultexte 7.

Back, H.- J.; Fürst, D. (2011): Der Beitrag von Hochschulen zur Entwicklung einer Region als „Wissensregion“. Hannover. = E-Paper der ARL 11

Barro, R.J.; Sala-i-Martin, X.I. (2003): Economic growth. Cambridge. Bartel, A.P.; Lichtenberg, F.R. (1987): The Comparative Advantage of Educated Workers in Implementing New Technology. In: The Review of Economics and Statistics 69, 1, 1-11. doi: $10.2307 / 1937894$ 
Bauer, E.M. (1997): Die Hochschule als Wirtschaftsfaktor: Eine systemorientierte und empirischeAnalyse universitätsbedingter Beschäftigungs-, Einkommens- und Informationseffekte dargestellt am Beispiel der Ludwig-Maximilians-Universität München. Kallmünz/Regensburg. = Münchner Studien zur Sozial- und Wirtschaftsgeographie 41.

Becker, G.S. (1964): Human Capital. A Theoretical and Analytical Analysis. New York.

Benson, L. (2000): Regionalwirtschaftliche Effekte von Hochschulen während inrer Leistungsabgabe. Theoretische Analyse und methodische Überlegungen zur Empirie. Trier. = Taurus Materialen 7.

Blackwell, M.; Cobb, S.; Weinberg, D. (2002): The Economic Impact of Educational Institutions: Issues and Methodology. In: Economic Development Quarterly 16, 1, 88-95. doi: 10.1177/0891242402016001009

Blume, L.; Fromm, O. (1999): Regionale Ausgabeneffekte von Hochschulen. In: Raumforschung und Raumordnung 57, 5-6, 418-431. doi:10.1007/BF03184510

Blume, L.; Fromm, O. (2000): Regionalökonomische Bedeutung von Hochschulen. Eine empirische Untersuchung am Beispiel der Universität Gesamthochschule Kassel. Wiesbaden. = Kasseler Wirtschafts- und Verwaltungswissenschaften 11. doi: 10.1007/978-3-663-08920-9

Bourdieu, P. (1979): Les trois états du capital culturel. In: Actes de la recherche en sciences sociales 30, 3-6.

Caffrey, J.; Isaacs, H.H. (1971). Estimating the Impact of a College or University on the Local Economy. Washington, DC.

Coleman, J.S. (1988): Social Capital in the Creation of Human Capital. In: American Journal of Sociology 94 (Supplement), S95-S120.

Criscuolo, C.; Haskel, J.; Slaughter, M.J. (2010): Global engagement and the innovation activities of firms. In: International Journal of Industrial Organization 28, 2, 191-202. doi: 10.1016/j. ijindorg.2009.07.012

Färber, G.; Dalezios, H.; Arndt, O.; Steden, P. (2007): Die Formale und Effektive Inzidenz von Bundesmitteln. Endbericht im Auftrag des Bundesministeriums für Verkehr, Bau und Stadtentwicklung (BMVBS) und des Bauamts für Bauwesen und Raumordnung (BBR). Speyer.

Farhauer, O.; Kröll, A. (2013): Standorttheorien: Regional- und Stadtökonomik in Theorie und Praxis. Wiesbaden. doi: 10.1007/978-3-658-05681-0

Fritsch, M. (2011): Start-ups in Innovative Industries: Causes and Effects. In: Audretsch, D.B.; Falck, O.; Heblich, S.; Lederer, A. (eds.): Handbook of Research on Innovation and Entrepreneurship. Cheltenham, 365-381.

Fuller, B.; Clarke, P. (1994): Raising School Effects while Ignoring Culture? Local Conditions and the Influence of Classroom Tools, Rules and Pedagogy. In: Review of Educational Research 64, 1, 119-157. doi: 10.3102/00346543064001119

Garrido-Yserte, R.; Gallo-Rivera, M.T. (2010): The impact of the university upon local economy: three methods to estimate demand-side effects. In: The Annals of Regional Science 44, 1, 39. doi: 10.1007/s00168-008-0243-x

Gerlach, A.; Sauer, T.; Stoetzer, M.-W. (2005): Formen und regionale Verteilung des Wissenstransfers von Hochschulen: Eine repräsentative Fallstudie für Jena. Jena. = Jenaer Beiträge zur Wirtschaftsforschung 1.
Glückler, J.; König, K. (2011): Die regionalwirtschaftliche Bedeutung der Universität Heidelberg. In: Meusburger, P.; Schuch, T. (eds.): Wissenschaftsatlas der Universität Heidelberg. Standorte und räumliche Beziehungen der Ruperto Carola in 625 Jahren. Knittlingen, 344-347.

Glückler, J.; Panitz, R.; Wuttke, C. (2015): Die wirtschaftliche Wirkung der Universitäten im Land Baden-Württemberg. In: Raumforschung und Raumordnung 73, 5, 327-342. doi: 10.1007/s13147-015-0360-9

Gries, T. (1995): Neue regionale Wachstumstheorie und Humankapital als regionaler charakteristischer Faktor. In: Gahlen, B.; Hesse, H.; Ramser, H.J. (eds.): Standort und Region. Neue Ansätze zur Regionalökonomik. Tübingen, 157188.

Hamm, R.; Kopper, J. (2016): Regionale Transfereffekte der Hochschule Niederrhein. Krefeld. = Mönchengladbacher Schriften zur wirtschaftswissenschaftlichen Praxis 29.

Hamm, R.; Wenke, M. (2002): Die Bedeutung von Fachhochschulen für die regionale Wirtschaftsentwicklung. In: Raumforschung und Raumordnung 60,1, 28-36. doi: 10.1007/BF03185691

Holub, H.-W.; Schnabel, H. (1994): Input-Output-Rechnung: InputOutput-Analyse. München.

Jaffe, A.B. (1989): Real Effects of Academic Research. In: The American Economic Review 79, 5, 957-970.

Kellaghan, T.; Sloane, K.; Alvarez, B.; Bloom, B.S. (1993): The Home Environment and School Learning: Promoting Parental Involvement in the Education of Children. San Francisco.

Knappe, S. (2006): Die Regionalwirksamkeit der Wissenschaftseinrichtungen in Potsdam: eine empirische Analyse Beschäftigungs-, Einkommensund Informationseffekte. Potsdam. = Praxis Kultur- und Sozialgeographie 40 .

Krueger, A.B.; Lindahl, M. (1999): Education for growth in Sweden and the world. In: Swedish Economic Policy Review 6, 289339

Leusing, B. (2007): Hochschulen als Standortfaktor. Eine empirische Analyse der regionalökonomischen Effekte der Universität Flensburg. Flensburg. = Universität Flensburg, Internationales Institut für Management, Discussion Paper 15.

Lucas, R.E. (1988): On the mechanics of economic development. In: Journal of Monetary Economics 22, 1, 3-42. doi: 10.1016/03043932(88)90168-7

Mansfield, E. (1991): Academic Research and Industrial Innovation. In: Research Policy 20, 1, 1-12. doi: 10.1016/00487333(91)90080-A

Mattes, A. (2012): Wirtschaftsfaktor TU Darmstadt. Die ökonomische Bedeutung der TU Darmstadt. Berlin.

Millo, G.; Piras, G. (2012): splm: Spatial Panel Data Models in R. In: Journal of Statistical Software 47, 1, 1-38.

Mincer, J. (1974): Schooling, Experience, and Earnings. New York. Nehru, V.; Swanson, E.; Dubey, A. (1995): A new database on human capital stock in developing and industrial countries: Sources, methodology, and results. In: Journal of Development Economics 46, 2, 379-401. doi: 10.1016/0304-3878(94)00054-G Nelson, R.R. (1959): The Simple Economics of Basic Scientific Research. In: Journal of Political Economy 67, 3, 297-306.

OECD - Organisation for Economic Co-operation and Development (2001): The Well-being of Nations. Paris. 
Oser, U.; Schroeder, E. (1995): Die Universität Konstanz als Wirtschaftsfaktor für die Region. Konstanz.

Pavel, F. (2008). Wirtschaftsfaktor TU Berlin: Welchen Einfluss hat die TU Berlin auf die Berliner Wirtschaft? Berlin.

Pellenbarg, P. (2007): How to Calculate the Impact of a University on the Regional Economy. A Case Study of the University of Groningen, the Netherlands. In: Kern, J.; Malinovsky, J.; Suchacek, J. (eds.): Learning Regions in Theory and Practice. Ostrava, 169-197.

Pfähler, W.; Bönte, W.; Gabriel, C.; Kettner, A. (1999): Wirtschaftsfaktor Bildung und Wissenschaft: die regionalwirtschaftliche Bedeutung der Hochschulbildungsund Wissenschaftseinrichtungen in Bremen. Frankfurt am Main.

Pfähler, W.; Clermont, C.; Gabriel, C.; Hofmann, U. (1997): Bildung und Wissenschaft als Wirtschafts- und Standortfaktor: die regionalwirtschaftliche Bedeutung der Hamburger Hochschulbildungs- und Wissenschaftseinrichtungen. Baden-Baden. = Veröffentlichungen des HWWA-Instituts für Wirtschaftsforschung 32.

Psacharopoulos, G. Patrinos, H.A. (2004): Returns to investment in education: a further update. In: Education Economics 12, 2, 111-134. doi: 10.1080/0964529042000239140

Putnam, R.D. (2000): Bowling alone: The Collapse and Revival of American Community. New York.

Romer, P.M. (1986): Increasing Returns and Long-Run Growth. In: Journal of Political Economy 94, 5, 1002-1037.

Romer, P.M. (1990): Endogenous technological change. In: Journal of Political Economy 98, 5, S71-S102.

Schamp, E.W.; Bathelt, H. (2002): Die Universität in ihrer Region - Eine Einführung. In: Bathelt, H.; Schamp, E.W. (eds.): Die Universität in der Region. Ökonomische Wirkungen der Johann Wolfgang Goethe-Universität in der Rhein-MainRegion. Frankfurt am Main, 1-7. = Frankfurter Wirtschafts- und Sozialgeographische Schriften 71.

Schubert, T.; Kroll, H. (2013): Endbericht zum Projekt „Hochschulen als regionaler Wirtschaftsfaktor". Im Auftrag von Stifterverband für die Deutsche Wissenschaft. Karlsruhe.

Schultz, T.W. (1963): The economic value of education. New York.

Spehl, H.; Sauerborn, K.; Sauer, M.; Benson, L.; Feser, H.-D.; von Malottki, C.; Schulze, P. M.; Flohr, M. (2005): Regionalwirtschaftliche Wirkungen der Hochschulen und Forschungseinrichtungen in Rheinland-Pfalz. Wertschöpfungs-, Einkommens- und Beschäftigungseffekte durch Bau und Betrieb der Einrichtungen. Langfassung der Forschungsergebnisse. Trier.

Stoetzer, M.-W.; Krähmer, C. (2007): Regionale Nachfrageeffekte der Hochschulen - methodische Probleme und Ergebnisse empirischer Untersuchungen für die Bundesrepublik Deutschland. Jena. $=$ Jenaer Beiträge zur Wirtschaftsforschung 6.

Stöver, B. (2018). The local impact and multiplier effect of universities in Lower Saxony on the labour market. Hannover. $=$ Hannover Economic Papers 646 .

Temple, J. (2001): Growth Effects of Education and Social Capital in the OECD Countries. In: Helliwell, J.F. (ed.): The Contribution of Human and Social Capital to Sustained Economic Growth and Well-being: International Symposium Report. Hull, 461501.
Tripp Umbach (2018): Economic Impact of University of Minnesota FY17. Minneapolis.

University of Colorado (2017): Economic impact study. Economic contribution of the University of Colorado on the state and counties of operations. Boulder.

Varga, A. (2006): Spatial Knowledge Spillovers and University Research: Evidence from Austria. In: Fischer, M.M. (ed.): Innovation, Networks, and Knowledge Spillovers. Berlin, 211232. doi: $10.1007 / 3-540-35981-8 \_10$

Warnecke, C. (2016): Universitäten und Fachhochschulen im regionalen Innovationssystem. Eine deutschlandweite Betrachtung. Bochum. = RUFIS Ruhr-Forschungsinstitut für Innovations- und Strukturpolitik 1/2016.

Wößmann, L. (2003): Schooling Resources, Educational Institutions and Student Performance: The International Evidence. In: Oxford Bulletin of Economics and Statistics 65, 2, 117-170. doi: 10.1111/1468-0084.00045 